\title{
Effective Hydrogen Peroxide Production from Electrochemical Water Oxidation
}

Sotirios Mavrikis ${ }^{\dagger, \neq *}$, Maximilian Göltz ${ }^{\S}$, Samuel C. Perry ${ }^{\dagger}$, Felix Bogdan ${ }^{\S}$, Pui Ki Leungף, Stefan Rosiwal ${ }^{\S *}$, Ling Wang ${ }^{\ddagger}$ and Carlos Ponce de León ${ }^{\dagger *}$

${ }^{\dagger}$ Electrochemical Engineering Laboratory, Energy Technology Research Group, Faculty of Engineering and Physical Sciences, University of Southampton, Highfield Campus, University Road, Southampton, SO17 1BJ, United Kingdom

${ }^{\ddagger}$ National Centre for Advanced Tribology at Southampton (nCATS), Faculty of Engineering and Physical Sciences, University of Southampton, Highfield Campus, University Road, Southampton, SO17 1BJ, United Kingdom

${ }^{\S}$ Chair of Materials Science and Engineering for Metals, Faculty of Engineering, Friedrich-Alexander University of Erlangen-Nürnberg, D-91058 Erlangen, Germany

"Key Laboratory of Low-grade Energy Utilization Technology \& Systems (LEUTS), Ministry of Education, Chongqing University, Chongqing, 400044, China

*Corresponding authors: s.mavrikis@soton.ac.uk; stefan.rosiwal@fau.de; capla@soton.ac.uk 
Table of Contents

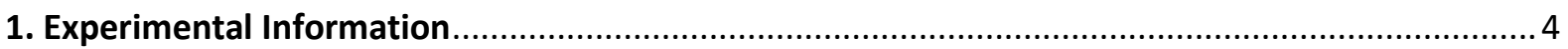

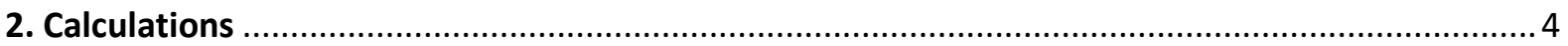

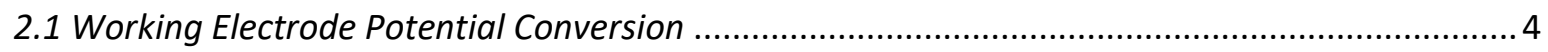

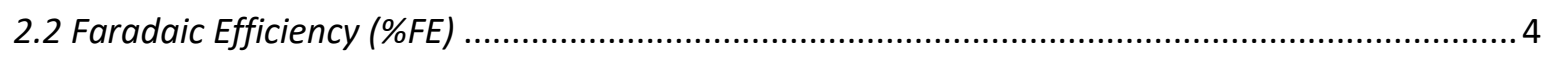

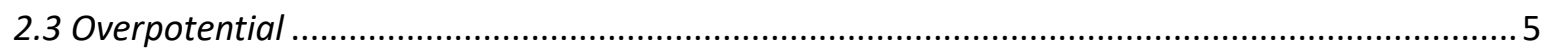

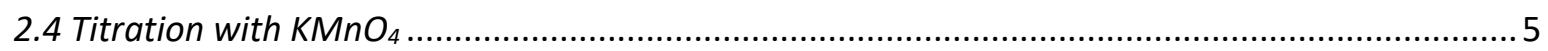

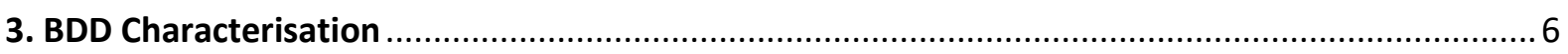

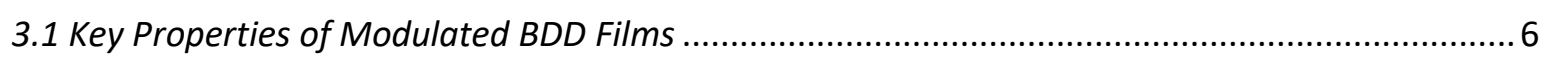

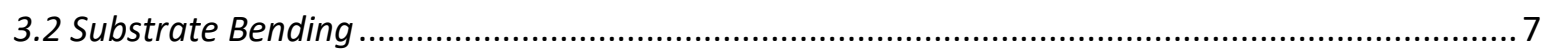

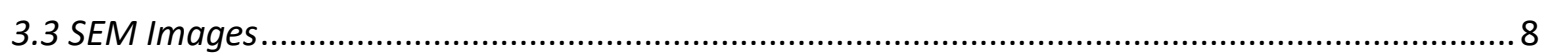

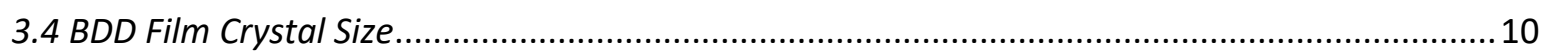

3.5 Boron Doping: Glow-Discharge Optical Emission Spectroscopy ..............................................11

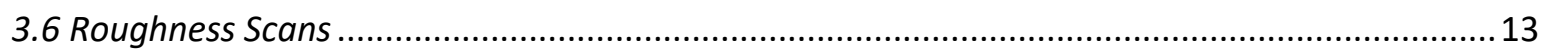

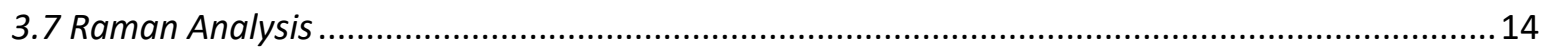

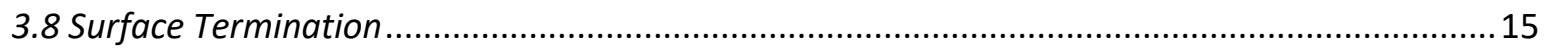

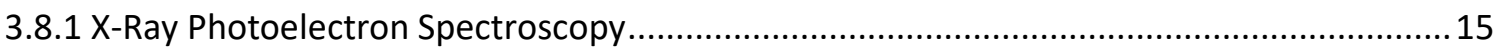

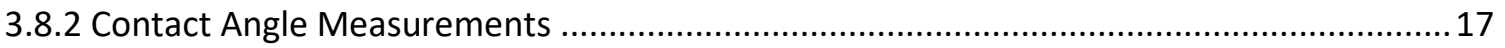

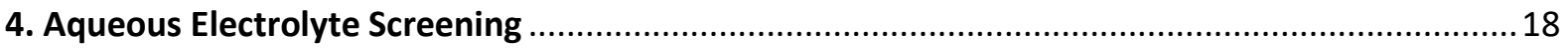

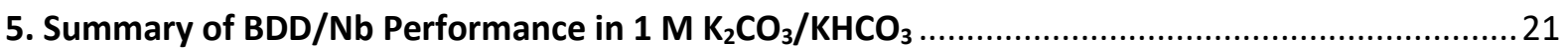

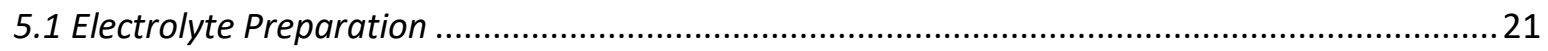

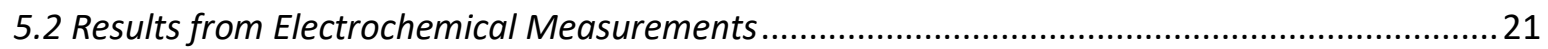

6. BDD Electrochemical Performance in Different Concentrations of Electrolyte ............................23

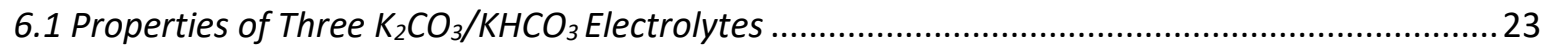

6.2 Results from Experiments Using BDD-4 and $\mathrm{BDD}-5$ in 0.5, 1 and $2 \mathrm{M}_{2} \mathrm{CO}_{3} / \mathrm{KHCO}_{3} \ldots \ldots \ldots \ldots \ldots . . . . . . . .23$

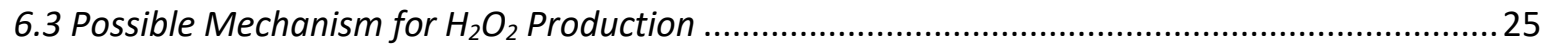

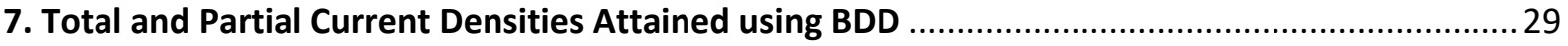

8. Performance Comparison of BDD to Other Prominent $2 e^{-}$WOR Electrocatalysts .......................30

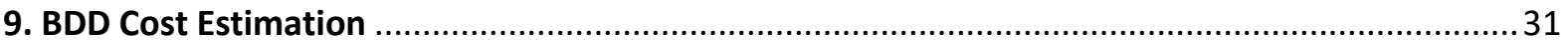

10. References 


\section{Experimental Information}

All reagents included in this study are of analytical grade, were used without further purification and were purchased from Merck (Sigma Aldrich), unless specified. All aqueous solutions are prepared using HPLC-grade water (Merck).

\section{Calculations}

\subsection{Working Electrode Potential Conversion}

A miniature $\mathrm{Hg} \mid \mathrm{HgO}$ reference electrode (RE-61AP, Bio-Logic Science Instruments Ltd), stored in $1 \mathrm{M}$ $\mathrm{NaOH}$ is used in all electrochemical measurements carried out within this study. To enable accurate and fair comparisons with electrode potentials (and overpotentials) reported elsewhere, the electrode potential is expressed versus the reversible hydrogen electrode (RHE) as shown in Equation S1.

$$
E_{\mathrm{RHE}}=E_{\mathrm{Hg} \mid \mathrm{HgO}}+(0.059 \times \mathrm{pH})+E_{\mathrm{Hg} \mid \mathrm{HgO}}^{0}
$$

where $E_{\mathrm{Hg} \mid \mathrm{HgO}}$ is the electrode potential recorded during electrolysis, the $\mathrm{pH}$ of the electrolyte is determined using a Jenway $3510 \mathrm{pH}$ meter, and $E_{\mathrm{Hg} \mid \mathrm{HgO}}^{0}$ is $0.140 \mathrm{~V}(1 \mathrm{M} \mathrm{NaOH})$.

\subsection{Faradaic Efficiency (\%FE)}

The faradaic efficiency (\%FE) for the two-electron water oxidation reaction $\left(2 e^{-} \mathrm{WOR}\right)$ is calculated via Equation S2, where $n_{\mathrm{H}_{2} \mathrm{O}_{2}}$ (experimental) is the amount of $\mathrm{H}_{2} \mathrm{O}_{2}$ (in mol) generated experimentally via electrolysis and is determined via titration with potassium permanganate $\left(\mathrm{KMnO}_{4}\right)$ \& sulfuric acid $\left(\mathrm{H}_{2} \mathrm{SO}_{4}\right) \cdot n_{\mathrm{H}_{2} \mathrm{O}_{2}}$ (theoretical) refers to the amount of $\mathrm{H}_{2} \mathrm{O}_{2}$ (in mol) calculated via Faraday's Law (Equation S3), where $Q$ is the charge passed during electrolysis, $z_{e}$ is the number of interchanged electrons and $F$ is the Faraday constant $\left(96,485.332 \mathrm{C} \mathrm{mol}^{-1}\right)$.

$$
\begin{aligned}
& \% F E=\left[\frac{n_{\mathrm{H}_{2} \mathrm{O}_{2}} \text { (experimental) }}{n_{\mathrm{H}_{2} \mathrm{O}_{2}} \text { (theoretical) }}\right] \times 100 \\
& Q=n_{\mathrm{H}_{2} \mathrm{O}_{2}} \text { (theoretical) } \times z_{e} \times F
\end{aligned}
$$


The overpotential $(\eta)$, is defined as the difference between the experimentally recorded electrode potential ( $\left.E_{\text {applied }}\right)$ at a given applied value of $j\left(\mathrm{~mA} \mathrm{~cm}^{-2}\right)$, and the thermodynamically derived standard

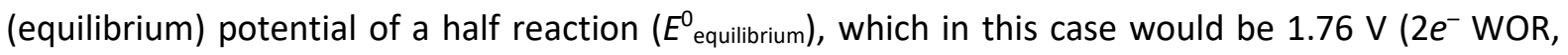
Equation 1). The overpotential, expressed in $\mathrm{mV}$, is calculated via Equation $\mathbf{S 4}$.

$\eta=E_{\text {applied }}-E_{\text {equilibrium }}^{0}$

\subsection{Titration with $\mathrm{KMnO}_{4}$}

The moles of $\mathrm{H}_{2} \mathrm{O}_{2}$ synthesised during electrolysis were determined via titration using $0.02 \mathrm{M}$ potassium permanganate $\left(\mathrm{KMnO}_{4}\right)$ and sulfuric acid $\left(\mathrm{H}_{2} \mathrm{SO}_{4}\right)$ as a proton source, based on Equation $\mathbf{S 5}$.

$2 \mathrm{MnO}_{4}^{-}{ }_{\text {(aq) }}+6 \mathrm{H}^{+}{ }_{\text {(aq) }}+5 \mathrm{H}_{2} \mathrm{O}_{2 \text { (aq) }} \rightarrow 2 \mathrm{Mn}^{2+}{ }_{\text {(aq) }}+8 \mathrm{H}_{2} \mathrm{O}_{(\text {(l) }}+5 \mathrm{O}_{2 \text { (g) }}$ 


\section{BDD Characterisation}

\subsection{Key Properties of Modulated BDD Films}

Table S1 Key properties of the modulated BDD catalyst films supported on Nb used in this work for the electrochemical production of $\mathrm{H}_{2} \mathrm{O}_{2}$ via the $2 e^{-}$WOR.

\begin{tabular}{|c|c|c|c|c|c|c|c|c|c|}
\hline $\begin{array}{c}\text { Sample } \\
\#\end{array}$ & $\begin{array}{l}\mathrm{B} / \mathrm{C} \\
\text { ratio }\end{array}$ & $\begin{array}{c}\text { B in } \\
\text { process } \\
\text { gas } \\
\text { (ppm) }\end{array}$ & $\begin{array}{c}\text { B } \\
\text { doping } \\
\text { in BDD } \\
\text { (ppm) }\end{array}$ & $\begin{array}{c}\text { Coating } \\
\text { thickness } \\
(\mu \mathrm{m})\end{array}$ & $\begin{array}{c}\text { Growth } \\
\text { Rate } \\
\left.(\mu \mathrm{m} \mathrm{h})^{-1}\right)\end{array}$ & $\begin{array}{l}\text { Roughness } \\
\qquad(\mu \mathrm{m})\end{array}$ & $\begin{array}{l}\text { Crystal } \\
\text { size } \\
(\mu \mathrm{m})\end{array}$ & $\begin{array}{c}\text { Geometric } \\
\mathrm{SA}\left(\mathrm{cm}^{2}\right)\end{array}$ & $\begin{array}{l}\text { Specific SA } \\
\left(\mu \mathrm{m}^{2} \mu \mathrm{m}^{-2}\right)\end{array}$ \\
\hline BDD-1 & 0.0025 & 30 & 5,500 & 2.3 & 0.230 & 7.5 & 0.37 & 8.96 & 2.57 \\
\hline BDD-2 & 0.0073 & 147 & 6,200 & 1.9 & 0.190 & 6.1 & 0.33 & 8.06 & 2.40 \\
\hline BDD-3 & 0.0081 & 99 & 10,500 & 2.0 & 0.133 & 5.0 & 0.43 & 6.84 & 2.44 \\
\hline BDD-4 & 0.012 & 148 & 12,600 & 2.0 & 0.125 & 4.4 & 0.43 & 6.84 & 2.41 \\
\hline BDD-5 & 0.012 & 148 & 14,000 & 1.2 & 0.120 & 7.5 & 0.40 & 8.68 & 2.70 \\
\hline BDD-6 & 0.016 & 198 & 16,200 & 4.0 & 0.190 & 4.3 & 0.53 & 6.84 & 2.27 \\
\hline
\end{tabular}

Table S2 The boron concentration of the six modulated BDD films expressed in ppm and atoms $\mathrm{cm}^{-3}$. The boron doping level is measured via glow-discharge optical emission spectroscopy (GDOES) calibrated in ppm standards. The conversion to atoms $\mathrm{cm}^{-3}$ is calculated via the equation: B doping (atoms $\left.\mathrm{cm}^{-3}\right)=$ atomic density of diamond $\times \mathbf{B}$ doping $(\mathrm{ppm}) \times 10^{6}$, where the atomic density of diamond is quantified via Avogadro's constant $\left(6.022 \times 10^{23} \mathrm{~mol}^{-1}\right)$, the molar mass of diamond $(12.011 \mathrm{~g}$ $\left.\mathrm{mol}^{-1}\right)$ and the density of diamond $\left(3.52 \mathrm{~g} \mathrm{~cm}^{-3}\right)$, and is found to be $1.76 \times 10^{23}$ carbon atoms $\mathrm{cm}^{-3}$.

\begin{tabular}{|c|c|c|}
\hline Sample \# & B doping in BDD (ppm) & B doping in BDD (atoms $\mathbf{~ c m}^{-3}$ ) \\
\hline BDD-1 & 5,500 & $9.71 \times 10^{20}$ \\
\hline BDD-2 & 6,200 & $1.09 \times 10^{21}$ \\
\hline BDD-3 & 10,500 & $1.85 \times 10^{21}$ \\
\hline BDD-4 & 12,600 & $2.22 \times 10^{21}$ \\
\hline BDD-5 & 14,000 & $2.47 \times 10^{21}$ \\
\hline BDD-6 & 16,200 & $2.86 \times 10^{21}$ \\
\hline
\end{tabular}




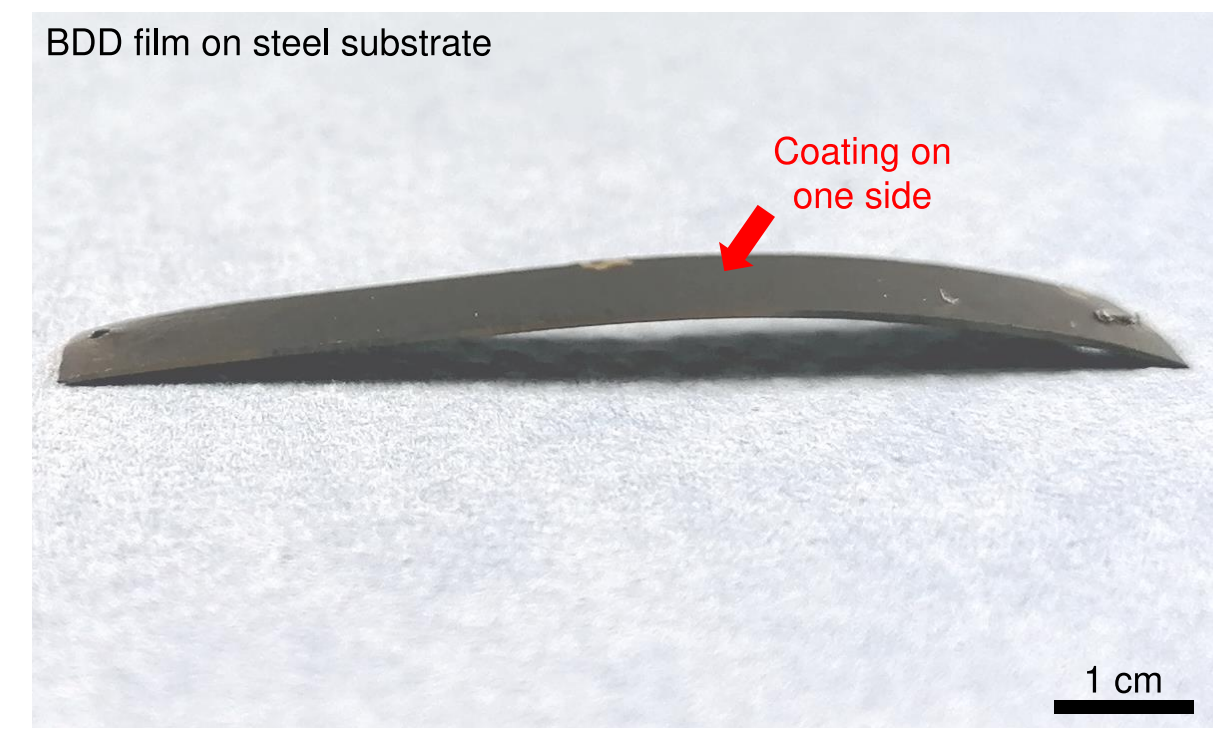

Figure S1 Photograph of a steel substrate coated with BDD on one side (upper). Due to a difference in the thermal expansion coefficient between the metal substrate and the diamond coating, stresses occur during the cooling process following the fabrication procedure. These stresses can reach pressures of several GPa and will bend any substrate coated on one side. Scale bar: $1 \mathrm{~cm}$.

Niobium ( $\mathrm{Nb}$ ) was ultimately selected as the metallic support for the modulated BDD films in this work as it can endure the high temperatures $\left(800^{\circ} \mathrm{C}\right)$ and hydrogen-based environment utilised for the growth of the diamond film. ${ }^{1}$ The formation of the metal-carbide (metal + carbon $\rightarrow$ metal-carbide) at the interlayer is slower for niobium $\left(-128 \mathrm{~kJ} \mathrm{~mol}^{-1}\right)$ than for titanium $\left(-172 \mathrm{~kJ} \mathrm{~mol}^{-1}\right)$ due to the higher Gibbs energy of formation. ${ }^{2}$ This thinner carbide layer on niobium (NbC) has several advantages regarding thermal stresses at the interface resulting from a mismatch of the thermal expansion coefficient, more desirable mechanical properties, and a favourable behaviour during oxidation (stable surface morphology for NbC following electrochemical oxidation). ${ }^{3}$ Finally, it has been shown that BDD coating delamination occurs twice as fast in BDD/Ti electrodes as opposed to BDD/Nb. ${ }^{4}$ Coating delamination in $\mathrm{BDD} / \mathrm{Ti}$ electrodes is observed in less than 24 hours compared to the 200 plus hours required for delamination to be observed in BDD/Nb electrodes. 


\subsection{SEM Images}
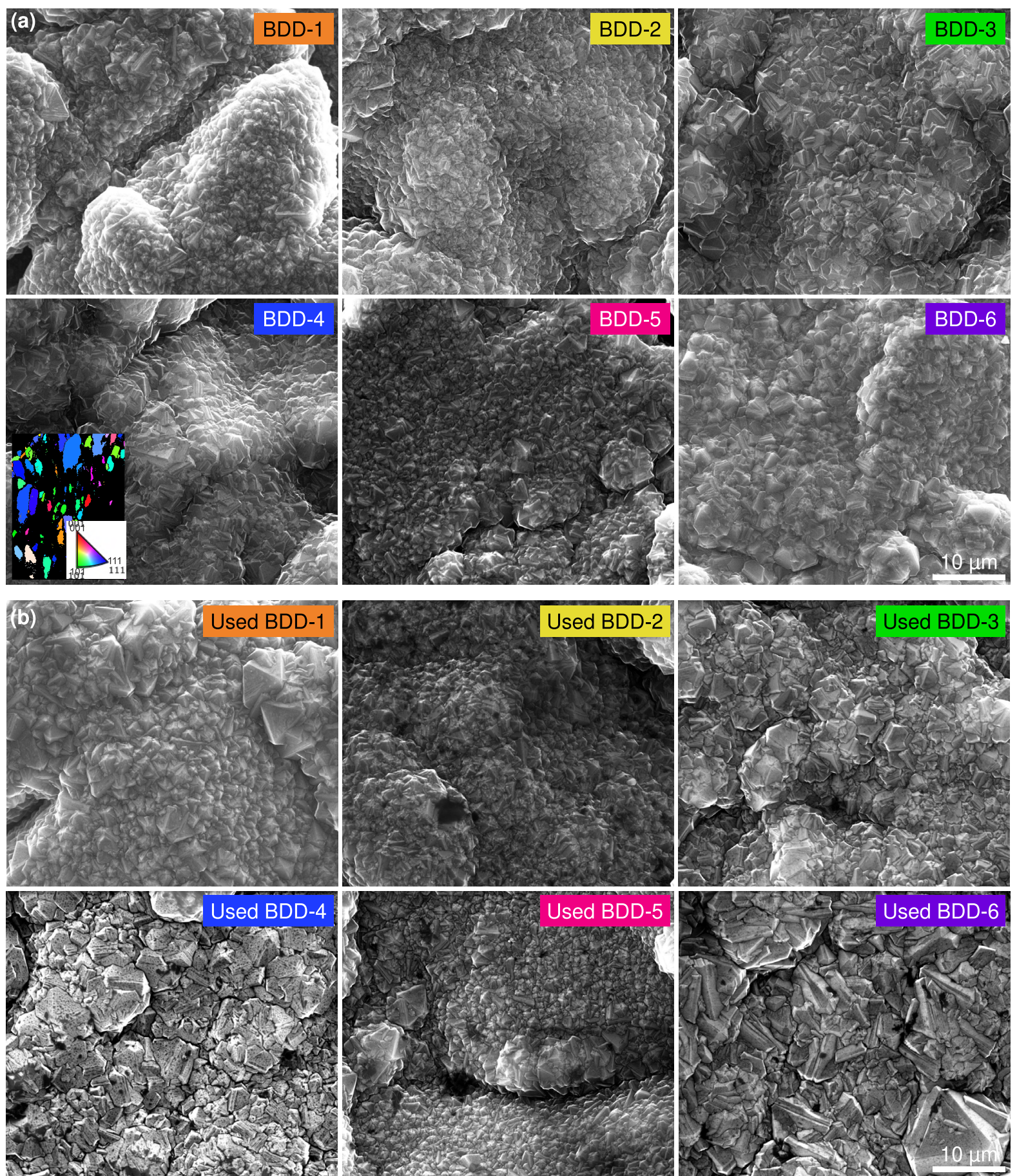

Figure S2 (a) Scanning Electron Microscopy (SEM) images of the six BDD films fabricated to produce $\mathrm{H}_{2} \mathrm{O}_{2}$ via the $2 e^{-}$WOR. Inset BDD-4 image: Electron Backscatter Diffraction (EBSD) analysis of BDD-4. (b) SEM images of the six 'used' BDD films following electrochemical experiments in $\mathrm{K}_{2} \mathrm{CO}_{3} / \mathrm{KHCO}_{3}$ to produce $\mathrm{H}_{2} \mathrm{O}_{2}$. Scale bar for all SEM micrographs: $10 \mu \mathrm{m}$. 
The SEM micrographs (FEI ESEM Quanta 450) shown in Figure S2 (a) exhibit non-texturised coatings with crystallite sizes below $1 \mu \mathrm{m}$. The diamond morphology of all six BDD films is very similar and consists primarily of (101) and (111) components. This is further corroborated by an EBSD (FEl Helios NanoLab 600i FI DualBeam) analysis (inset) carried out on BDD-4. Non-evaluated black areas seen in the EBSD inset occur due to the small crystal size of the BDD coating and are consistent with results reported in other studies. ${ }^{5}$ The formation of twin-boundaries (low energy grain boundaries) is observed in all six BDD coatings as is common for mixed textured coatings. ${ }^{6}$ Additionally, the niobium substrate is completely coated; no uncoated and exposed areas are visible. The underlying uneven structure of the BDD films originates from the particle blasting pre-treatment.

Figure S2 (b) shows the BDD coatings following electrochemical experiments at applied current densities between $50-300 \mathrm{~mA} \mathrm{~cm}{ }^{-2}$ in $\mathrm{K}_{2} \mathrm{CO}_{3} / \mathrm{KHCO}_{3}$. In comparison to the as-produced micrographs (Figure S2a), fewer crystallites growing near the grain boundaries, or edges from secondary nucleation are observed, resulting in a clean crystalline morphology. This observed etching of the $\mathrm{sp}^{2}$ and boronrich carbon phases agrees with the literature, ${ }^{7}$ and may account for the general increase in the median crystallite size. 
(a)

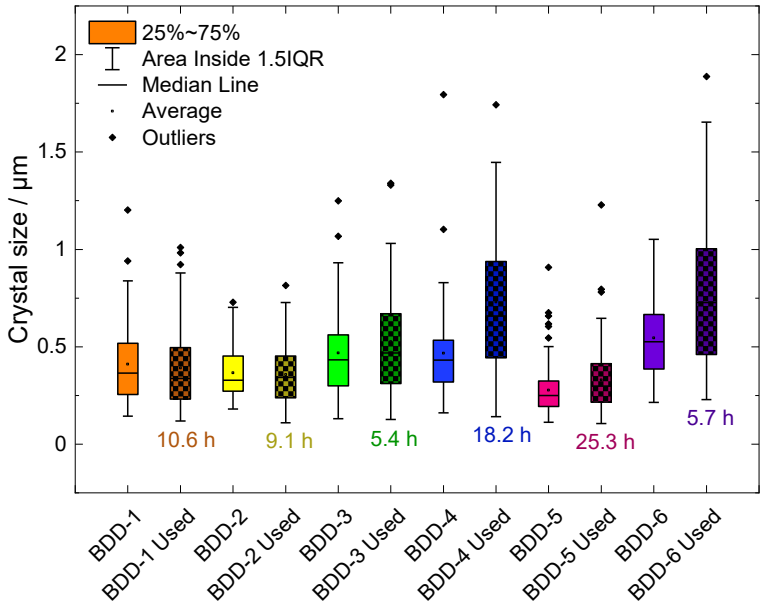

(b)

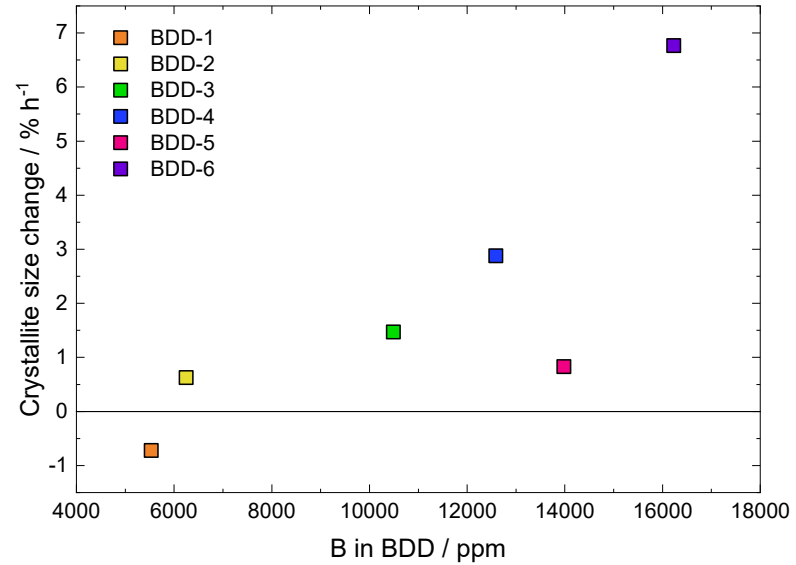

Figure S3 (a) Crystallite size distribution estimated via the 'average line-intercept' method for the as-produced and used BDD coatings. 'Used' refers to BDD/Nb electrodes that have been subjected to multiple hours of electrolysis (total usage shown in h). (b) The change in the crystallite size per hour of electrolysis as a function of boron concentration in BDD.

The median crystal size of the BDD films is estimated from the SEM micrographs using the 'average line-intercept' method. ${ }^{8}$ Though more commonly used to estimate the grain size of polished films, the method yields a reliable crystallite distribution to characterise the different BDD coatings. The crystallite sizes between the six BDD films are very similar, ranging between 0.4-1 $\mu \mathrm{m}$ (Figure S3a). The post-electrolysis, 'used' BDD films reveal a general trend toward larger crystallite sizes possibly as a result of etching of the non-sp ${ }^{3}$ carbon on the grain boundaries, and the small secondary nuclei formed on the crystallite facets based on the usage time (ranging between 5-25 h)

The correlation between the change in the crystallite size normalised to the usage time of the BDD/Nb anodes as a function of the boron doping level in the BDD films is shown in Figure $\mathbf{S 3}$ (b). The change in the crystal size is proportional to the boron concentration: a higher B doping level results in a stronger change in the crystallite size per hour of anodic usage. Based on the literature, ${ }^{7,9}$ it is hypothesised that the $\mathrm{sp}^{2}$ and boron-rich carbon phases, commonly seen at grain boundaries and in newly formed secondary nuclei, ${ }^{10}$ are more easily etched during anodic use of the BDD/Nb anodes. By increasing the charge passed through the BDD film, the coating is etched much faster than the stable diamond phase, thereby resulting in a 'cleaning' effect where smaller crystallites are removed. Longerused coatings like BDD- 5 exhibit a minimal change in the crystallite size as further etching after the initial oxidation of the $\mathrm{sp}^{2}$ and B-rich carbon phases will increase the $\mathrm{sp}^{3} / \mathrm{sp}^{2}$ carbon ratio, leading to a more stable, $\mathrm{sp}^{3}$-carbon dominant BDD film. 
(a)

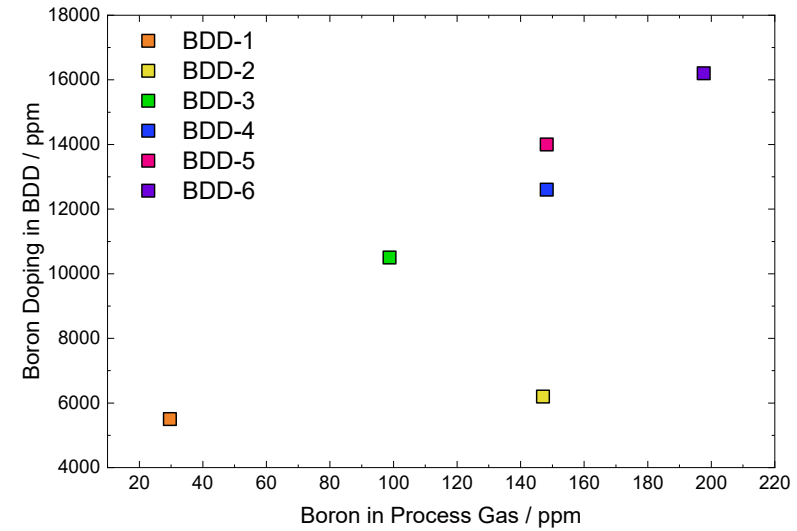

(b)

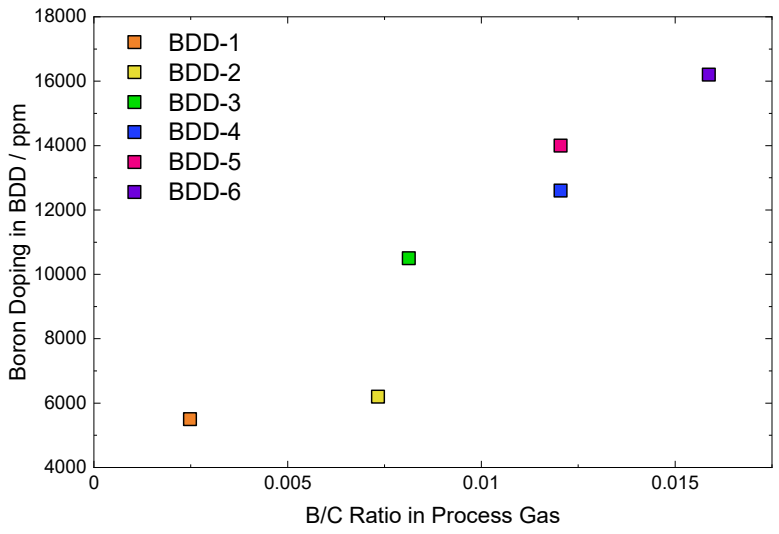

Figure S4 (a) The boron doping level of each BDD coating as a function of the boron concentration in the process gas phase. (b) The boron doping level of each BDD coating as a function of the boron-to-carbon ratio $(B / C)$ in the process gas phase.

The boron content in each BDD coating is measured using glow-discharge optical emission spectroscopy (GDOES, Horiba GD-Profiler 1 calibrated by mass spectrometry standards) and exhibits a linear correlation with the boron concentration in the gas phase, with the exception of BDD-2 (Figure $\mathbf{S 4 a}$ ). When considering the $\mathrm{B} / \mathrm{C}$ ratio for the $\mathrm{BDD}$ films during the coating process (Figure $\mathbf{S 4 b}$ ), a more linear correlation is observed, confirming that the incorporation of boron in the diamond lattice is highly dependent on the general film growth conditions, including the concentration of methane used which is twice that of the other process gases. ${ }^{11-14}$

The different boron concentrations for BDD-4 and BDD- 5 at equal values for $B$ and $B / C$ in the process gas may be attributed to the longer coating time and increased coating thickness and crystal size for BDD-4 (Table S1). The incorporation of boron in the diamond lattice is more facile at grain boundaries. Fewer grain boundaries in BDD-4 may account for the lower overall boron doping level. ${ }^{10}$ 


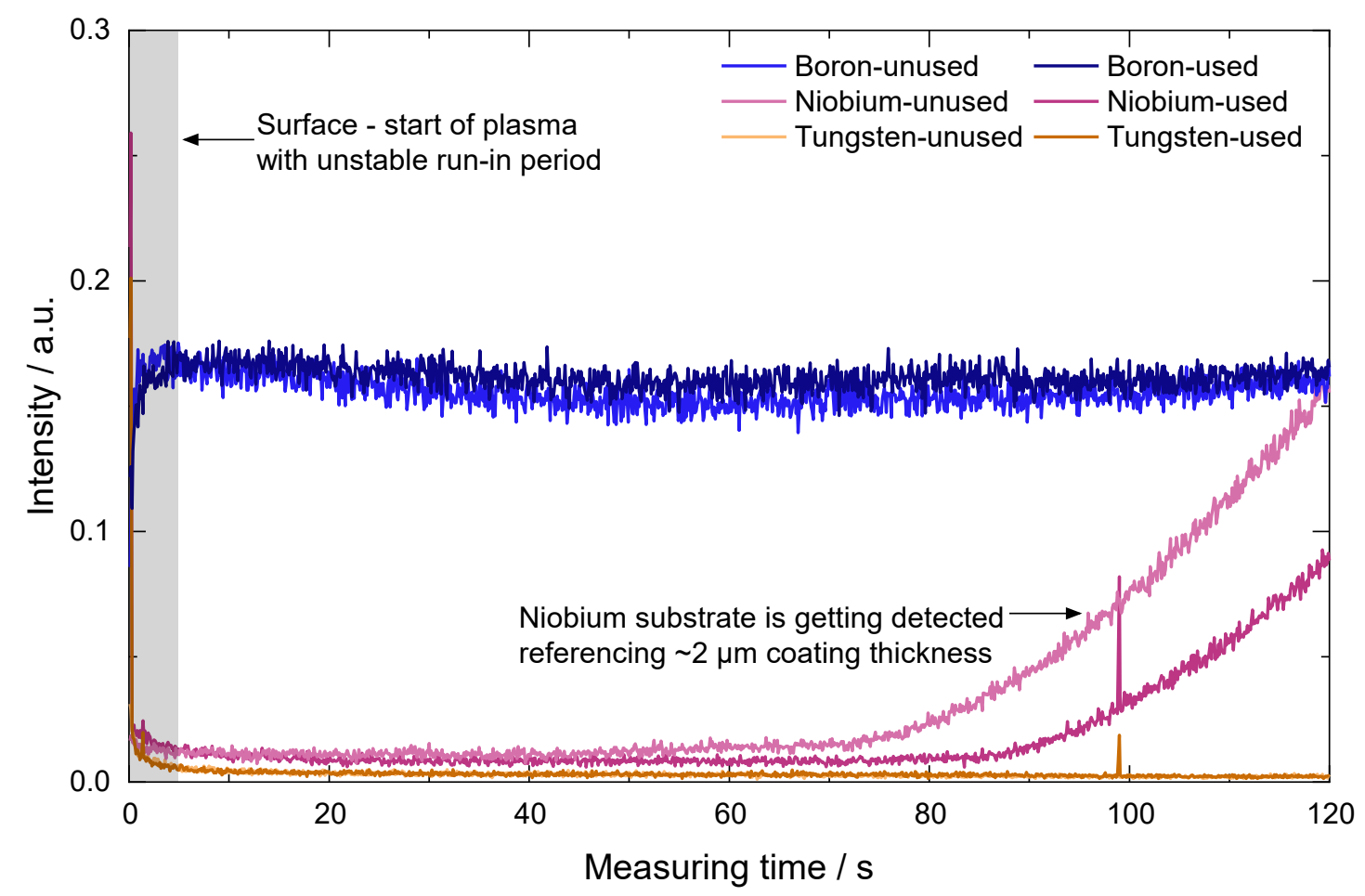

Figure S5 GDOES measurement of different elements found in BDD-1 before and after anodic usage.

The intensity of the measurement current over the analysis time is depicted in Figure S5. The greycoloured area occurring at approximately $5 \mathrm{~s}$ shows the run-in period, while the increase of the light and dark pink-coloured signals indicates the gradual detection of the niobium substrate upon which the BDD film is supported. The grey-coloured run-in (or stabilising) period observed at approximately $\mathrm{t}=5 \mathrm{~s}$ following ignition of the plasma at $\mathrm{t}=0 \mathrm{~s}$ underscores the disadvantage of analysing the topmost surface of the BDD film using this method as the measured values are not completely reliable. That is the region where possible etching of the unstable phases (boron or graphitic carbon) would occur. Nonetheless, it is possible to surmise that the bulk-phase of the BDD-1 layer exhibits no noticeable changes concerning the concentration of boron following electrochemical oxidation for at least 10.6 h. For possible tungsten contamination of the BDD, the photocurrent is equal to the dark current indicating that the concentration of $W$ is below the detection limit of $100 \mathrm{ppm}$. 

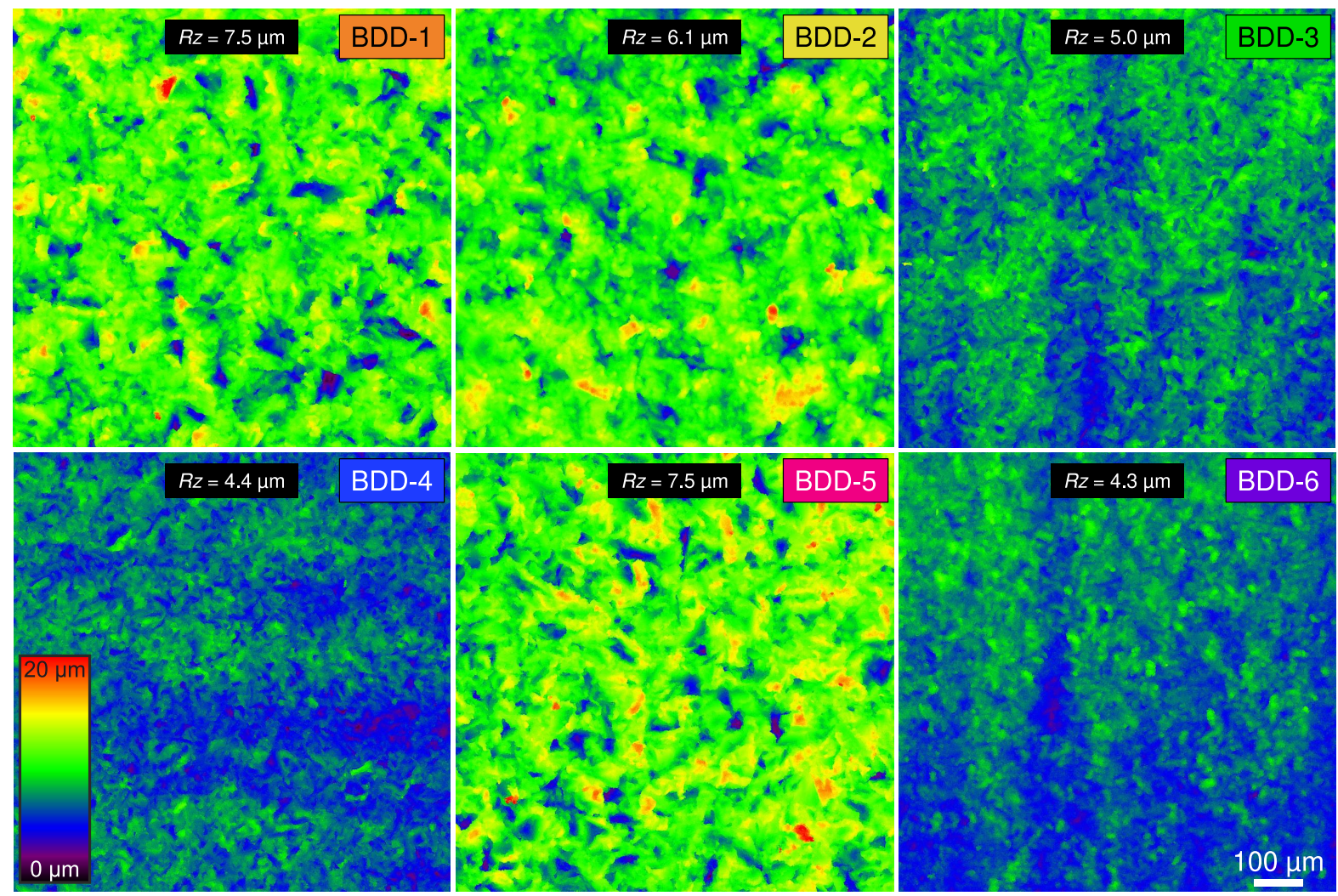

Figure $\mathbf{S 6}$ Laser scanning microscopy (LSM) images of the six BDD film surfaces. The scans show topologies with an $R z$ value range of 4.3-7.5 $\mu \mathrm{m}$, with BDD-4 and BDD-6 exhibiting the lowest roughness values ( 4.4 and $4.3 \mu \mathrm{m}$, respectively) while BDD5 has the highest $R z$ value of $7.5 \mu \mathrm{m}$. Scale bar for all BDD coatings: $100 \mu \mathrm{m}$.

An analysis of the laser scanning microscopy (LSM) images taken of the BDD films produced via particle blasting provides further information on the topology of the BDD surface (Figure S6). The roughness value $R z$ is taken from line measurements based on ISO 4287-1:1984, while the specific surface is evaluated using a flooding model or volume measurement via LSM. The specific surface is expressed in real surface area per geometric area $\left(\mu \mathrm{m}^{2} \mu \mathrm{m}^{-2}\right)$. The roughness varies distinctly between $4.3 \mu \mathrm{m}$ (BDD-6) to $7.5 \mu \mathrm{m}$ (BDD-5), while the specific surface has a lower deviation of 2.3 (BDD-6) to 2.7 (BDD$5)$. This observation could be attributed to the higher structure amplitude of the rougher BDD films (BDD-1, BDD-2, BDD-5), compared to the higher frequency in the roughness of samples (BDD-3, BDD4, BDD-6). 


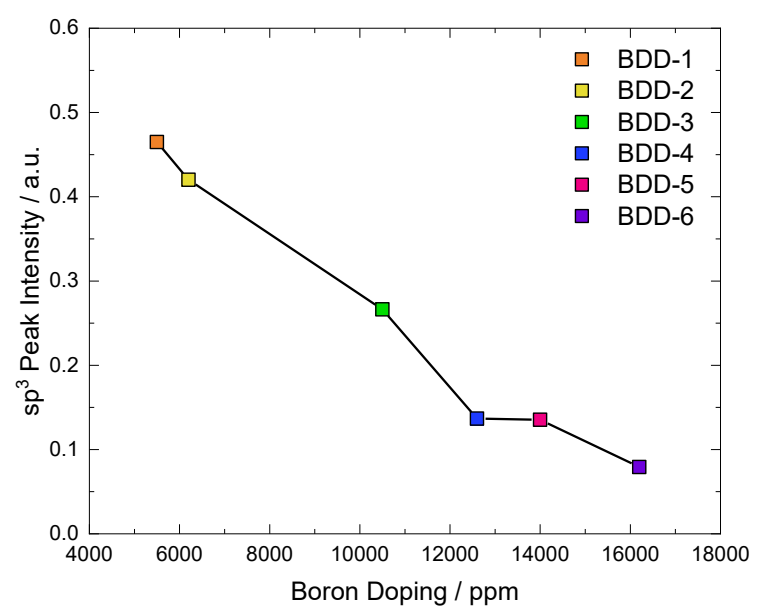

Figure S7 The intensity of the $\mathrm{sp}^{3}$ peak at $1332 \mathrm{~cm}^{-1}$ for the six BDD coatings as a function of the boron doping level.

Boron incorporation in the diamond lattice results in a decrease of the intensity of the diamond peak. This decrease can be attributed to scattering at boron impurities, the expansion of the diamond lattice and the electronic Raman interaction that distorts and shifts the diamond peak from its original position at $1332 \mathrm{~cm}^{-1}$ towards lower wave numbers. The Raman analysis was completed using a Horiba LabRAM ARAMIS spectrometer with an excitation wavelength of $532 \mathrm{~nm}$. 


\subsection{Surface Termination}

The BDD films fabricated via the hot-filament CVD process are hydrogen terminated (H-terminated) upon leaving the reaction chamber. Anodic pre-treatment is carried out to convert the H-terminated BDD film to oxygen terminated (O-terminated). ${ }^{15,16}$ Oxidation is performed by applying a constant potential of $+3 \mathrm{~V}$ vs. $\mathrm{Ag} \mid \mathrm{AgCl}$ (saturated $\mathrm{KCl}$, BioLogic Sciences Instruments) in $0.1 \mathrm{M} \mathrm{H}_{2} \mathrm{SO}_{4}$ for $60 \mathrm{~s}$. Following each chronoamperometry measurement in $\mathrm{H}_{2} \mathrm{SO}_{4}$, LSV measurements are carried out in 1 $\mathrm{M} \mathrm{K}_{2} \mathrm{CO}_{3} / \mathrm{KHCO}_{3}$ at a scan rate of $20 \mathrm{mV} \mathrm{s}^{-1}$. Each experiment is repeated five times.

\subsubsection{X-Ray Photoelectron Spectroscopy}

X-ray photoelectron spectroscopy (taken with an Physical Electronics 5600 system using an Al Ka monochromatic $X$ Ray source, where the correction was shifted on the carbon peak at $284.8 \mathrm{eV}$, the take-off angle was $45^{\circ}$, the energy step size is $0.2 \mathrm{eV}$ and the spot diameter is $800 \mu \mathrm{m}$ ) measurements were performed to determine the surface termination of several BDD-4 coatings that were pretreated via anodic polarisation and compare them to the as-produced film. Figure $\mathbf{S 8}$ shows the deconvoluted $\mathrm{C}$ 1s spectra of each BDD-4 coating, along with the fitted peaks associated with different surface groups, following anodic pre-treatment under different conditions. Interpretation of the XPS spectra recorded for the modified BDD-4 film was carried out based on the existing literature. ${ }^{17}$

For the as-produced BDD-4 coating (Figure S8a), the signals associated with hydrogenated carbon [C$C(1)$ and $C-C(2)]$ are much stronger than for the anodically treated films. For the anodically polarised BDD-4 coatings (Figure $\mathbf{S 8 b} \mathbf{b} \mathbf{d}$ ), the peaks indicating the presence of oxygen groups are stronger and the hydrogen signal is noticeably smaller. The variations between the anodically treated BDD-4 films are minor. Based on the XPS spectra, it can be concluded that:

1) The as-produced, untreated BDD coatings are hydrogen terminated (H-terminated)

2) After short anodic usage ( $\sim \mathrm{min}$ ) the BDD surface becomes oxygen terminated (Oterminated)

3) Anodic polarisation produces mostly similar O-terminations after a short period of time, regardless of the electrolyte used $\left(0.1 \mathrm{M} \mathrm{H}_{2} \mathrm{SO}_{4} ; 1 \mathrm{M} \mathrm{K}_{2} \mathrm{CO}_{3} / \mathrm{KHCO}_{3}\right.$; combination) 
(a)

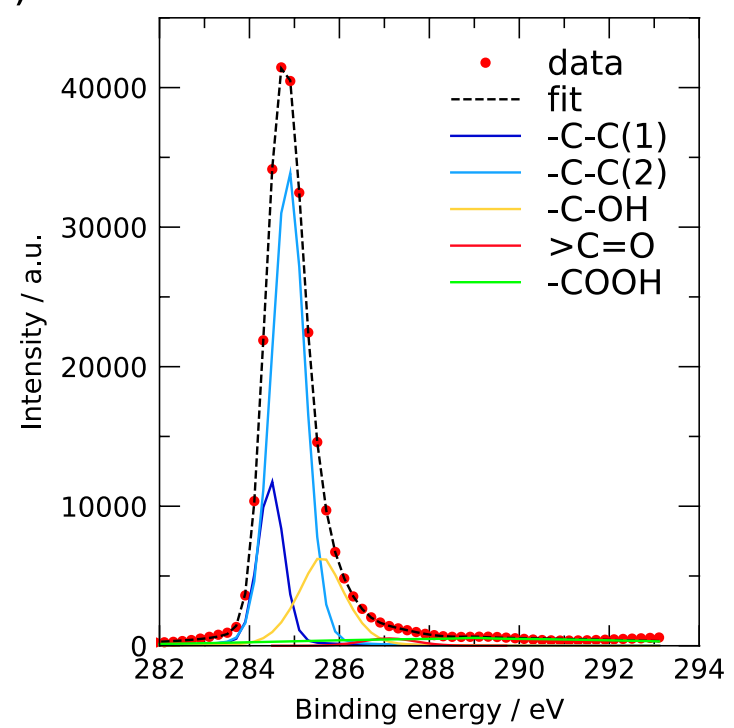

(c)

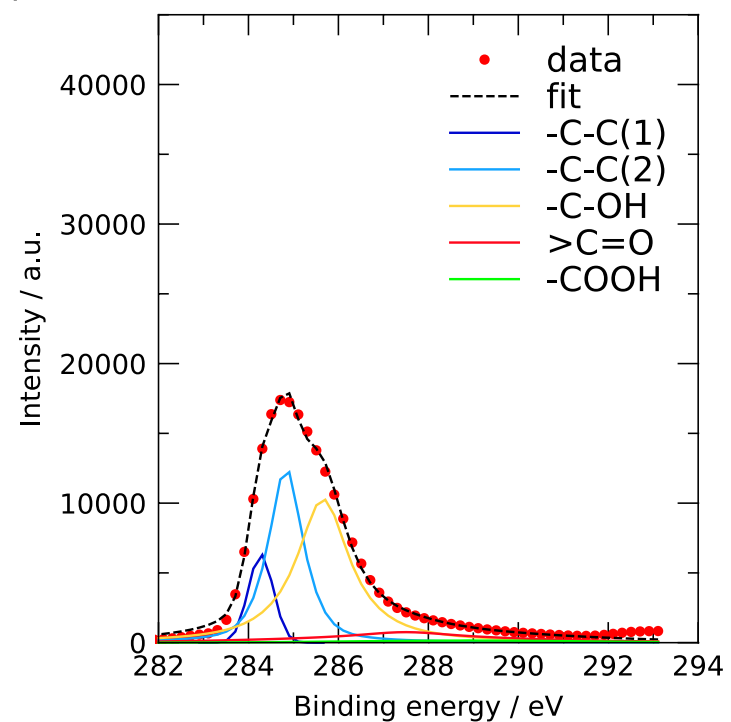

(b)

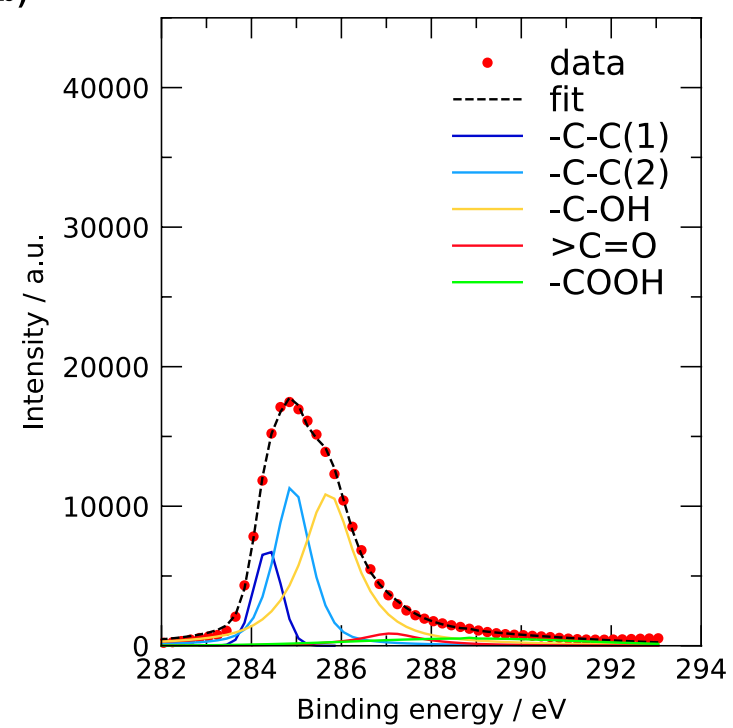

(d)

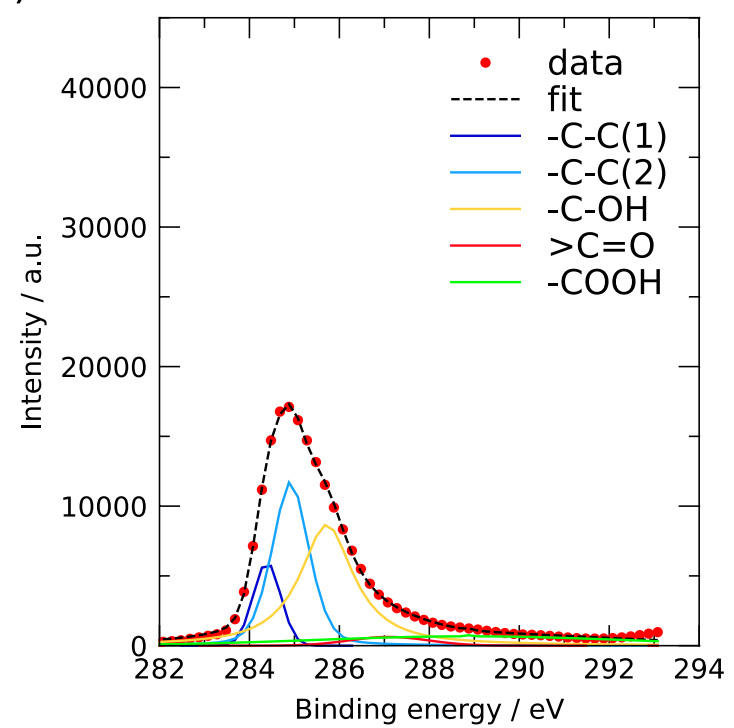

Figure $\mathbf{5 8}$ XPS analysis showing the deconvoluted C 1s spectra of the as-produced and oxidised BDD-4 films. The spectra exhibit different ratios for the surface termination components. (a) The untreated, as-produced BDD-4 coating shows distinctly stronger signals associated with hydrogenated carbon than the anodically treated BDD-4 coatings. (b) BDD-4 anodically pre-treated in $0.1 \mathrm{M} \mathrm{H}_{2} \mathrm{SO}_{4}$ for a total of $5 \mathrm{~min}$. (c) BDD-4 anodically pre-treated in $1 \mathrm{M} \mathrm{K}_{2} \mathrm{CO}_{3} / \mathrm{KHCO}_{3}$ for a total of $5 \mathrm{~min}$. (d) BDD-4 anodically pre-treated in various electrolytes $\left(\mathrm{H}_{2} \mathrm{SO}_{4}, \mathrm{~K}_{2} \mathrm{CO}_{3}, \mathrm{~K}_{2} \mathrm{CO}_{3} / \mathrm{KHCO}_{3}\right)$ for a total of $18.2 \mathrm{~h}$. 


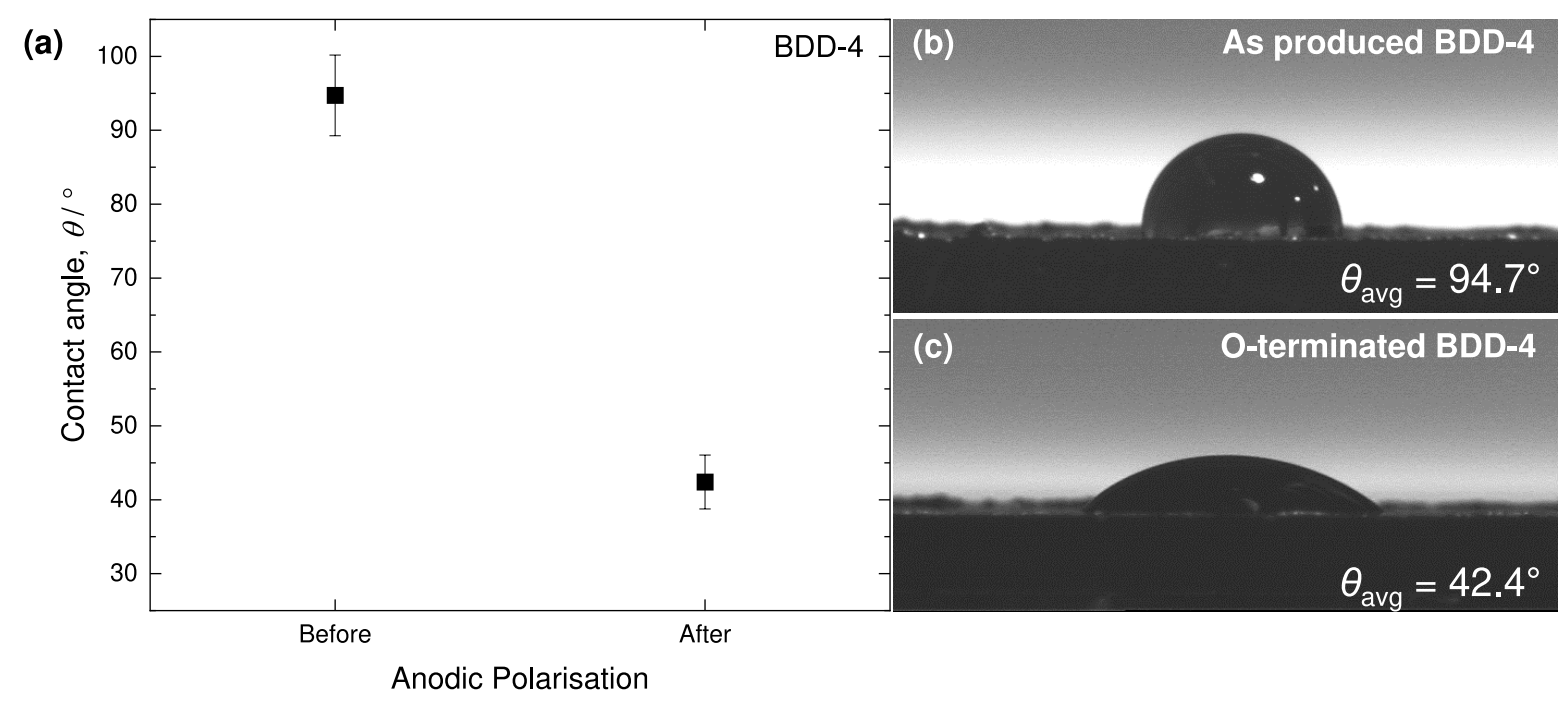

Figure S9 (a) Average contact angle measurements taken before and after anodic polarisation of BDD-4 $\left(6.66 \mathrm{~cm}^{2}\right)$. (b) photograph of a water droplet on the surface of as-produced BDD-4. (c) photograph of a water droplet on anodically-treated (5 min in $0.1 \mathrm{M} \mathrm{H}_{2} \mathrm{SO}_{4}$ and five LSVs in $1 \mathrm{M} \mathrm{K}_{2} \mathrm{CO}_{3} / \mathrm{KHCO}_{3}$ ) BDD-4.

A Krüss Drop Shape Analyser 100 (DSA 100) in combination with a glass syringe fitted with a PTFE tip was used to place ultra-pure deionised water droplets of $5 \mu \mathrm{L}$ in the centre of the BDD film surface. Ultra-pure deionised water droplets of $5 \mu \mathrm{L}$ were positioned in the middle of the substrate surface. A photograph is captured swiftly to minimise evaporation effects. Two anchor markers are manually positioned to mark the contact points of the droplet with the substrate surface. A circle-fitting profile traces the edges of the droplet and the contact angle is measured. The process is repeated five times for each $\mathrm{BDD} / \mathrm{Nb}$ electrode to calculate an average contact angle (Figure S9a). The average contact angle for the untreated BDD-4 film is shown to be $94.7^{\circ}( \pm 5.47$ ) (Figure S9b), well in agreement with the literature for highly hydrophobic $\mathrm{H}$-terminated BDD surfaces. ${ }^{18} \mathrm{~A}$ notable decrease in the water contact angle is observed upon anodic polarisation of BDD-4 (Figure S9c) with $\vartheta_{\text {avg }}=42.4^{\circ}( \pm 3.61$ ), which falls within the range of $0.6-65^{\circ}$ for O-terminated BDD surfaces, ${ }^{17-20}$ further corroborating the XPS analysis shown in Figure $\mathbf{S 8}$ and thus confirming that the BDD films in this work are $\mathrm{O}$-terminated. 


\section{Aqueous Electrolyte Screening}

The two-electron water oxidation performance of BDD was evaluated in six different carbonate and hydrogen carbonate (bicarbonate) electrolytes. The key parameters for each supporting electrolyte are summarised in Table S3.

Table S3 Carbonate and bicarbonate electrolytes investigated for the $2 e^{-}$WOR to produce $\mathrm{H}_{2} \mathrm{O}_{2}$ using BDD catalytic films.

\begin{tabular}{|c|c|c|c|}
\hline Inorganic Compound & Concentration (M) & $\mathbf{p H}$ & Conductivity $\left(\mathbf{m S ~ c m}^{-\mathbf{1}}\right)$ \\
\hline $\mathrm{NaHCO}_{3}$ & 1.2 (sat.) & 7.99 & 55.53 \\
\hline $\mathrm{Na}_{2} \mathrm{CO}_{3}$ & 1 & 11.67 & 78.80 \\
\hline $\mathrm{KHCO}_{3}$ & 2 & 8.23 & 120.0 \\
\hline $\mathrm{K}_{2} \mathrm{CO}_{3}$ & 1 & 12.15 & 138.4 \\
\hline $\mathrm{CsHCO}_{3}$ & 2 & 8.47 & 123.0 \\
\hline $\mathrm{Cs}_{2} \mathrm{CO}_{3}$ & 1 & 12.20 & 143.0 \\
\hline
\end{tabular}

Linear sweep voltammetry is performed to determine the onset potential for the WOR to evolve $\mathrm{O}_{2}$ (and thus generate $\mathrm{H}_{2} \mathrm{O}_{2}$ ) in the different electrolytes using BDD-5 at an applied electrode potential range of approximately 2.0-3.4 V vs. RHE (Figure S10a) with a scan rate of $20 \mathrm{mV} \mathrm{s}^{-1}$. The specific bias range is selected as it is the potential window where BDD-5 will have reached $100 \mathrm{~mA} \mathrm{~cm}$ in all the examined aqueous electrolytes. In $1 \mathrm{M} \mathrm{Cs}_{2} \mathrm{CO}_{3}, \mathrm{BDD}-5$ reaches $100 \mathrm{~mA} \mathrm{~cm}{ }^{-2}$ at $2.99 \mathrm{~V}$ vs. RHE, the lowest potential value of all the electrolytes investigated, while in saturated $\mathrm{NaHCO}_{3}, \mathrm{BDD}-5$ reaches the same $j$ value at $3.36 \mathrm{~V}$ vs. RHE. This is expected as $\mathrm{Cs}_{2} \mathrm{CO}_{3}$ is more conductive than $\mathrm{NaHCO}_{3}(\mathrm{Table}$ S3). The other four electrolytes reach $100 \mathrm{~mA} \mathrm{~cm}{ }^{-2}$ within the potential range established by $\mathrm{Cs}_{2} \mathrm{CO}_{3}$ and $\mathrm{NaHCO}_{3}$. The linear sweep voltammogram (LSV) indicates that caesium-based carbonate electrolytes would be the most suitable of the three different cation-carbonate/bicarbonate solutions $\left(\mathrm{K}^{+}, \mathrm{Na}^{+}\right.$and $\left.\mathrm{Cs}^{+}\right)$for the $2 e^{-}$WOR (which occurs within the sharp OER peak observed in the LSV). 
(a)

(c)

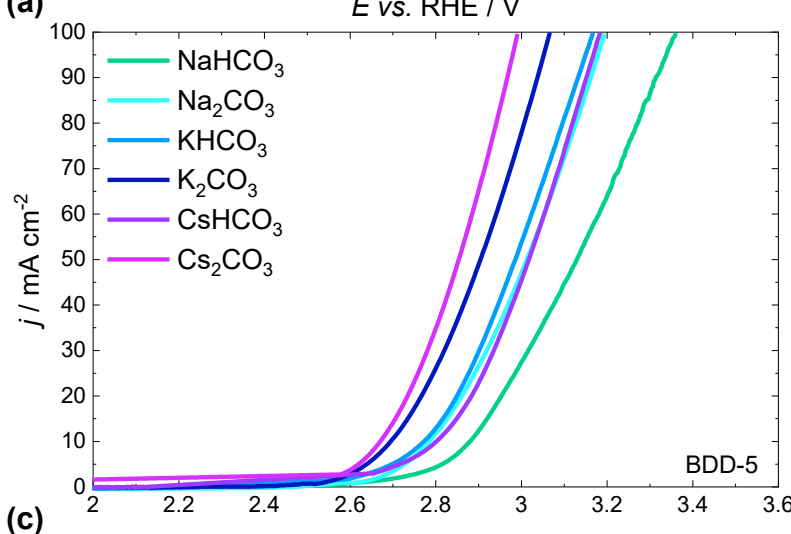

(b)

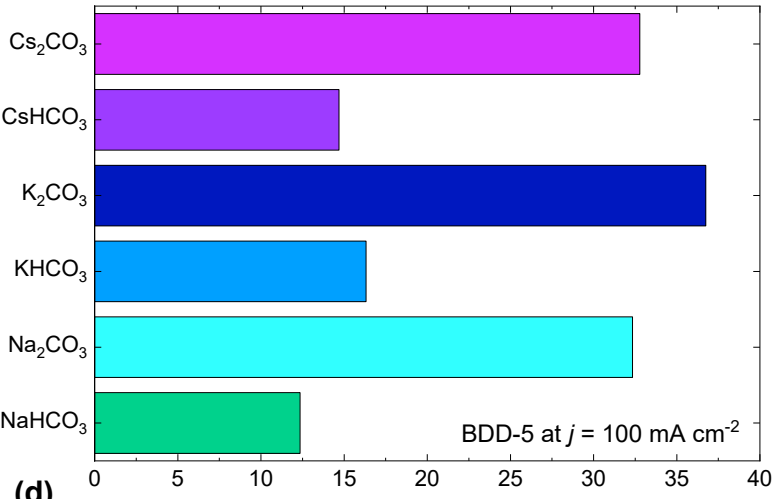

(d)

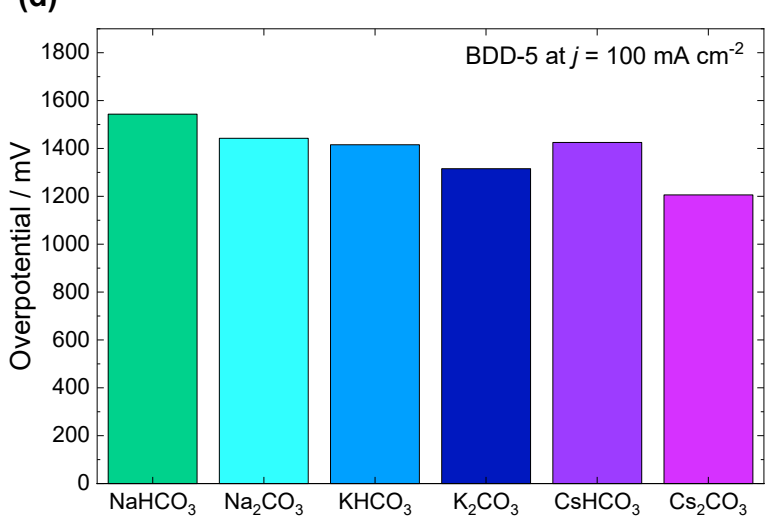

Figure S10 Electrolysis of sample BDD-5 in six different electrolytes (sat. $\mathrm{NaHCO}_{3}, 1 \mathrm{M} \mathrm{Na}_{2} \mathrm{CO}_{3}, 2 \mathrm{M} \mathrm{KHCO}, 1 \mathrm{M} \mathrm{K}_{2} \mathrm{CO}_{3}, 2 \mathrm{M}$ $\mathrm{CsHCO}_{3}$ and $1 \mathrm{M} \mathrm{Cs}_{2} \mathrm{CO}_{3}$ ). (a) Linear sweep voltammogram (LSV) of BDD-5 (SA $=8.68 \mathrm{~cm}^{2}$ ) at an applied electrode potential of 0-3.4 V vs. RHE. (b) $\mathrm{H}_{2} \mathrm{O}_{2}$ concentration after electrolysis at $100 \mathrm{~mA} \mathrm{~cm}^{-2}$ for $300 \mathrm{~s}$ in the six different aqueous supporting electrolytes. (c) $\% \mathrm{FE}$ for $\mathrm{H}_{2} \mathrm{O}_{2}$ production at $100 \mathrm{~mA} \mathrm{~cm}^{-2}$ in each electrolyte as a function of the recorded electrode potential (RHE). (d) Overpotential calculated at $100 \mathrm{~mA} \mathrm{~cm}^{-2}$ in each investigated electrolyte using BDD/Nb-5.

The $\mathrm{H}_{2} \mathrm{O}_{2}$ concentration values detected in each solution after a $300 \mathrm{~s}$ constant-current test at $j=100$ $\mathrm{mA} \mathrm{cm}{ }^{-2}$ using BDD-5 can be seen in Figure $\mathbf{S 1 0}$ (b). The most striking observation is that the three carbonate solutions produce more than twice the amount of $\mathrm{H}_{2} \mathrm{O}_{2}$ as their respective bicarbonate counterparts. Of the three carbonate solutions, $\mathrm{K}_{2} \mathrm{CO}_{3}$ produces the most $\mathrm{H}_{2} \mathrm{O}_{2}$, reaching a concentration of $36.7 \mathrm{mM}$. $\mathrm{Cs}_{2} \mathrm{CO}_{3}$ and $\mathrm{Na}_{2} \mathrm{CO}_{3}$ reach $\mathrm{H}_{2} \mathrm{O}_{2}$ concentrations of 32.8 and $32.3 \mathrm{mM}$, respectively, also high values for the $2 e^{-}$WOR. $\mathrm{NaHCO}_{3}, \mathrm{KHCO}_{3}$ and $\mathrm{CsHCO}_{3}$ attain $12.3,16.3$ and 14.7 $\mathrm{mM}$ of $\mathrm{H}_{2} \mathrm{O}_{2}$, respectively. These results contrast with those reported by Fuku et al., where $\mathrm{KHCO}_{3}$ was identified as the most suitable supporting electrolyte for increased concentrations of $\mathrm{H}_{2} \mathrm{O}_{2} \cdot{ }^{21}$ The Sayama research group reported their observations using a $\mathrm{BiVO}_{4} / \mathrm{WO}_{3}$ catalyst, whereas $\mathrm{BDD}$ is used in this study, therefore the possible intermediates formed in carbonate using $\mathrm{BDD}\left(\mathrm{HO} \mathrm{O}^{\circ}, \mathrm{C}_{2} \mathrm{O}_{6}{ }^{2-}\right)$ could favour $\mathrm{H}_{2} \mathrm{O}_{2}$ formation over the intermediates formed in bicarbonate using metal oxides or BDD. This is further evident when considering the $\% F E$ for $\mathrm{H}_{2} \mathrm{O}_{2}$ production in each electrolyte (Figure $\mathrm{S10c}$ ). The general trend is similar to that of the $\mathrm{H}_{2} \mathrm{O}_{2}$ concentration: a higher \%FE in the carbonate electrolyte; a lower \%FE in the bicarbonate solutions. This agrees with an experimentally-observed increase in $\mathrm{O}_{2}$ evolution (in the form of bubbles) when using bicarbonate compared to carbonate. It is conceivable that the competing OER is more prominent in bicarbonate than carbonate, hence the disparities in the \%FE. The highest efficiency for $\mathrm{H}_{2} \mathrm{O}_{2}$ synthesis is attained in $\mathrm{K}_{2} \mathrm{CO}_{3}$ at $68.3 \%$; the lowest in $\mathrm{NaHCO}_{3}$ at just $23 \%$. As expected however, the $\% \mathrm{FE}$ in $\mathrm{Cs}_{2} \mathrm{CO}_{3}$, an impressive $61 \%$ is reached at $2.97 \mathrm{~V} v$ s. $\mathrm{RHE}$, $100 \mathrm{mV}$ lower than the \%FE attained in $\mathrm{K}_{2} \mathrm{CO}_{3}$. 
The overpotential is a crucial parameter to consider when evaluating electrocatalysts for the $2 e^{-} \mathrm{WOR}$, yet the supporting electrolyte seems to have an active role in determining the overpotential, possibly due to the selected salt's conductivity. $\mathrm{Cs}_{2} \mathrm{CO}_{3}$, which has the lowest overpotential, $1210 \mathrm{mV}$ (when calculating the overpotential at $100 \mathrm{~mA} \mathrm{~cm}^{-2}$ ) is also the most conductive of the six compounds investigated, while $\mathrm{NaHCO}_{3}$, the least conductive electrolyte tested, has the highest overpotential, $1540 \mathrm{mV}$ (Figure S10d). An exception to this hypothesis is $\mathrm{CsHCO}_{3}$ which is more conductive than both potassium-based electrolytes yet possesses a higher overpotential than both: $1430 \mathrm{mV}$ compared to $1420 \mathrm{mV}$ and $1320 \mathrm{mV}$ for $\mathrm{KHCO}_{3}$ and $\mathrm{K}_{2} \mathrm{CO}_{3}$, respectively.

While a low overpotential at increased currents $\left(\geq 100 \mathrm{~mA} \mathrm{~cm}{ }^{-2}\right)$ is highly desirable, large $\mathrm{H}_{2} \mathrm{O}_{2}$ production rates and a high selectivity toward $\mathrm{H}_{2} \mathrm{O}_{2}$ are paramount in advancing the scalability of the $2 e^{-}$WOR and cannot be sacrificed. Caesium is also amongst the world's most expensive chemical elements and therefore $\mathrm{Cs}_{2} \mathrm{CO}_{3}$ and $\mathrm{CsHCO}_{3}$ are very costly and unsuitable for large-scale implementation. ${ }^{22}$ Given that $\mathrm{K}_{2} \mathrm{CO}_{3}$ achieved the highest values for $\% F E$ and $v_{\mathrm{H}_{2} \mathrm{O}_{2}}$, it seems like an obvious choice as an electrolyte. $\mathrm{K}_{2} \mathrm{CO}_{3}$ is very alkaline however $(1 \mathrm{M}, \mathrm{pH} \sim 12.15)$ and will lead to rapid $\mathrm{H}_{2} \mathrm{O}_{2}$ decomposition. Alkaline solutions are generally unfavourable for the stability of $\mathrm{H}_{2} \mathrm{O}_{2} .{ }^{23}$ One way to circumvent this issue is to combine $\mathrm{K}_{2} \mathrm{CO}_{3}$ with $\mathrm{KHCO}_{3}$ leading to two highly desirable benefits:

1. A decrease in the electrolyte's $\mathrm{pH}(\sim 10)$ to the mildly alkaline values more commonly employed that will additionally curtail $\mathrm{H}_{2} \mathrm{O}_{2}$ decomposition. ${ }^{24}$

2. An increase in the electrolyte's conductivity to a value higher than that of $\mathrm{Cs}_{2} \mathrm{CO}_{3}$, possibly resulting in lower overpotentials. 


\section{Summary of $\mathrm{BDD} / \mathrm{Nb}$ Performance in $1 \mathrm{M} \mathrm{K}_{2} \mathrm{CO}_{3} / \mathrm{KHCO}_{3}$}

\subsection{Electrolyte Preparation}

The combined, potassium carbonate and bicarbonate supporting electrolyte is prepared by adding 1 $\mathrm{M} \mathrm{KHCO} 3$ to $1 \mathrm{M} \mathrm{K}_{2} \mathrm{CO}_{3}$, corresponding to a salt ratio of 1:1 $\left(\mathrm{K}_{2} \mathrm{CO}_{3}: \mathrm{KHCO}_{3}\right)$. The prepared solution is thus named ' $1 \mathrm{M} \mathrm{K}_{2} \mathrm{CO}_{3} / \mathrm{KHCO}_{3}$ ' and its primary properties are summarised in Table S4. The addition of $\mathrm{KHCO}_{3}$ to $\mathrm{K}_{2} \mathrm{CO}_{3}$ decreases the $\mathrm{pH}$ to a mildly alkaline value of 9.8 (compared to the very alkaline $\mathrm{K}_{2} \mathrm{CO}_{3}$ ) and increases the conductivity of the solution.

Table S4 Key properties of the combined $\mathrm{K}_{2} \mathrm{CO}_{3} / \mathrm{KHCO}_{3}$ aqueous supporting electrolyte used in this study.

\begin{tabular}{|c|c|c|c|c|}
\hline Inorganic Compound & $\begin{array}{c}\mathrm{K}_{2} \mathrm{CO}_{3} \text { Concentration } \\
\text { (M) }\end{array}$ & $\begin{array}{c}\mathrm{KHCO}_{3} \text { Concentration } \\
\text { (M) }\end{array}$ & $\mathbf{p H}$ & $\begin{array}{c}\text { Conductivity } \\
\left(\mathbf{m S ~ c m}^{-1}\right)\end{array}$ \\
\hline $\mathrm{K}_{2} \mathrm{CO}_{3} / \mathrm{KHCO}_{3}$ & 1 & 1 & 9.8 & 188.0 \\
\hline
\end{tabular}

\subsection{Results from Electrochemical Measurements}

Table $\mathrm{S5} \mathrm{H}_{2} \mathrm{O}_{2}$ concentration, partial current density, efficiency, and rate of each BDD catalytic film in $1 \mathrm{M} \mathrm{K}_{2} \mathrm{CO}_{3} / \mathrm{KHCO}_{3}$. Values presented are averaged upon collecting three data points $(n=3)$ for each applied current.

\begin{tabular}{|c|c|c|c|c|c|}
\hline \multicolumn{6}{|c|}{ BDD-1 } \\
\hline E vs. RHE (V) & $\begin{array}{c}j_{\text {Total }} \\
\left(\mathrm{mA} \mathrm{cm}^{-2}\right)\end{array}$ & $\begin{array}{c}j_{\mathrm{H}_{2} \mathrm{O}_{2}} \\
(\mathrm{~mA} \mathrm{~cm})\end{array}$ & $\mathrm{H}_{2} \mathrm{O}_{2}(\mathrm{mM})$ & FE (\%) & $V_{\mathrm{H}_{2} \mathrm{O}_{2}}\left(\mu \mathrm{mol} \mathrm{cm} \mathrm{cm}^{-2} \mathrm{~min}^{-1}\right)$ \\
\hline 2.74 & 50 & 25 & 13.9 & 50 & 7.7 \\
\hline 2.82 & 100 & 61 & 34.1 & 61 & 19.0 \\
\hline 2.95 & 150 & 97 & 53.8 & 65 & 30.0 \\
\hline 3.08 & 200 & 130 & 72.0 & 65 & 40.2 \\
\hline 3.12 & 250 & 149 & 82.7 & 60 & 46.1 \\
\hline 3.22 & 300 & 168 & 93.3 & 56 & 52.0 \\
\hline \multicolumn{6}{|c|}{ BDD-2 } \\
\hline E vs. RHE (V) & $\begin{array}{c}j_{\text {Total }} \\
\left.(\mathrm{mA} \mathrm{cm})^{-2}\right)\end{array}$ & $\begin{array}{c}j_{\mathrm{H}_{2} \mathrm{O}_{2}} \\
\left(\mathrm{~mA} \mathrm{~cm}^{-2}\right)\end{array}$ & $\mathrm{H}_{2} \mathrm{O}_{2}(\mathrm{mM})$ & FE (\%) & $V_{\mathrm{H}_{2} \mathrm{O}_{2}}\left(\mu \mathrm{mol} \mathrm{cm} \mathrm{cm}^{-2} \mathrm{~min}^{-1}\right)$ \\
\hline 2.70 & 50 & 31 & 15.4 & 62 & 9.6 \\
\hline 2.80 & 100 & 63 & 31.5 & 63 & 19.5 \\
\hline 2.95 & 150 & 102 & 51.0 & 68 & 31.7 \\
\hline 2.97 & 200 & 128 & 63.8 & 64 & 39.6 \\
\hline 3.01 & 250 & 145 & 72.3 & 58 & 44.9 \\
\hline 3.05 & 300 & 166 & 82.9 & 55 & 51.4 \\
\hline \multicolumn{6}{|c|}{ BDD-3 } \\
\hline E vs. RHE (V) & $\begin{array}{c}j_{\text {Total }} \\
\left.(\mathrm{mA} \mathrm{cm})^{-2}\right)\end{array}$ & $\begin{array}{c}j_{\mathrm{H}_{2} \mathrm{O}_{2}} \\
\left(\mathrm{~mA} \mathrm{~cm}^{-2}\right)\end{array}$ & $\mathrm{H}_{2} \mathrm{O}_{2}(\mathrm{mM})$ & FE (\%) & $V_{\mathrm{H}_{2} \mathrm{O}_{2}}\left(\mu \mathrm{mol} \mathrm{cm}^{-2} \mathrm{~min}^{-1}\right)$ \\
\hline 2.68 & 50 & 30 & 11.7 & 60 & 8.6 \\
\hline
\end{tabular}




\begin{tabular}{|c|c|c|c|c|c|}
\hline 2.81 & 100 & 62 & 24.1 & 62 & 17.6 \\
\hline 2.88 & 150 & 93 & 36.4 & 62 & 26.6 \\
\hline 2.97 & 200 & 125 & 52.9 & 62 & 38.6 \\
\hline 3.01 & 250 & 156 & 66.3 & 63 & 48.5 \\
\hline 3.09 & 300 & 177 & 75.0 & 59 & 54.8 \\
\hline \multicolumn{6}{|c|}{ BDD-4 } \\
\hline E vs. RHE (V) & $\begin{array}{c}j_{\text {Total }} \\
\left(\mathrm{mA} \mathrm{cm}^{-2}\right)\end{array}$ & $\begin{array}{c}j_{\mathrm{H}_{2} \mathrm{O}_{2}} \\
\left(\mathrm{~mA} \mathrm{~cm}^{-2}\right)\end{array}$ & $\mathrm{H}_{2} \mathrm{O}_{2}(\mathrm{mM})$ & FE (\%) & $V_{\mathrm{H}_{2} \mathrm{O}_{2}}\left(\mu \mathrm{mol} \mathrm{cm} \mathrm{cm}^{-2} \mathrm{~min}^{-1}\right)$ \\
\hline 2.66 & 50 & 28 & 12.0 & 57 & 8.8 \\
\hline 2.79 & 100 & 66 & 27.8 & 66 & 20.3 \\
\hline 2.91 & 150 & 98 & 41.7 & 66 & 30.5 \\
\hline 3.00 & 200 & 140 & 59.2 & 70 & 43.3 \\
\hline 3.05 & 250 & 173 & 73.5 & 69 & 53.7 \\
\hline 3.10 & 300 & 208 & 88.2 & 69 & 64.5 \\
\hline \multicolumn{6}{|c|}{ BDD-5 } \\
\hline E vs. RHE (V) & $\begin{array}{c}j_{\text {Total }} \\
\left(\mathrm{mA} \mathrm{cm}^{-2}\right)\end{array}$ & $\begin{array}{c}j_{\mathrm{H}_{2} \mathrm{O}_{2}} \\
\left(\mathrm{~mA} \mathrm{~cm}^{-2}\right)\end{array}$ & $\mathrm{H}_{2} \mathrm{O}_{2}(\mathrm{mM})$ & FE (\%) & $V_{\mathrm{H}_{2} \mathrm{O}_{2}}\left(\mu \mathrm{mol} \mathrm{cm} \mathrm{cmin}^{-1}\right)$ \\
\hline 2.64 & 50 & 26 & 13.9 & 52 & 8.0 \\
\hline 2.73 & 100 & 62 & 33.3 & 62 & 19.2 \\
\hline 2.78 & 150 & 102 & 54.7 & 68 & 31.5 \\
\hline 2.84 & 200 & 120 & 64.8 & 60 & 37.3 \\
\hline 2.92 & 250 & 150 & 80.8 & 60 & 46.6 \\
\hline 2.95 & 300 & 168 & 90.4 & 56 & 52.1 \\
\hline \multicolumn{6}{|c|}{ BDD-6 } \\
\hline E vs. RHE (V) & $\begin{array}{c}j_{\text {Total }} \\
\left(\mathrm{mA} \mathrm{cm}^{-2}\right)\end{array}$ & $\begin{array}{c}j_{\mathrm{H}_{2} \mathrm{O}_{2}} \\
\left(\mathrm{~mA} \mathrm{~cm}^{-2}\right)\end{array}$ & $\mathrm{H}_{2} \mathrm{O}_{2}(\mathrm{mM})$ & FE (\%) & $V_{\mathrm{H}_{2} \mathrm{O}_{2}}\left(\mu \mathrm{mol} \mathrm{cm}^{-2} \mathrm{~min}^{-1}\right)$ \\
\hline 2.68 & 50 & 29 & 12.3 & 58 & 9.0 \\
\hline 2.78 & 100 & 59 & 25.1 & 59 & 18.4 \\
\hline 2.88 & 150 & 91 & 38.6 & 61 & 28.2 \\
\hline 2.98 & 200 & 131 & 55.6 & 66 & 40.6 \\
\hline 3.07 & 250 & 161 & 68.2 & 64 & 49.9 \\
\hline 3.13 & 300 & 184 & 78.0 & 61 & 57.0 \\
\hline
\end{tabular}

BDD-4 (B: 12,600 ppm; thickness: $2 \mu \mathrm{m}$ ) and BDD-5 (B: 14,000 ppm; thickness: $1.2 \mu \mathrm{m}$ ) are identified as the most active and selective films investigated due to a combination of high \% FEs and $\mathrm{V}_{\mathrm{H}_{2} \mathrm{O}_{2}}$ at low overpotentials (particularly for BDD-5). BDD-1 (B: 5,500 ppm; thickness: $2.3 \mu \mathrm{m}$ ) generated the most $\mathrm{H}_{2} \mathrm{O}_{2}$ overall in $1 \mathrm{M} \mathrm{K}_{2} \mathrm{CO}_{3} / \mathrm{KHCO}_{3}$, possibly due to its high roughness and surface area $(R z 7.5 \mu \mathrm{m}$ and $\mathrm{SA} 8.96 \mathrm{~cm}^{2}$ ) albeit at much larger overpotentials due to its lower $B$ doping level compared to BDD-4 and BDD-5 (2-3 $\times$ lower). A higher B doping level doesn't necessarily guarantee a better overall electrocatalytic performance, as BDD-6 (B: 16,200 ppm; thickness: $4 \mu \mathrm{m}$ ) records lower values for the $\% F E$ and $v_{\mathrm{H}_{2} \mathrm{O}_{2}}$ at higher overpotentials compared to BDD-4 and BDD-5, possibly due to its coating being 2-3 $\times$ thicker. The overall superior activity and selectivity of BDD-4 may be attributed to a combination of factors: a lower $R z$ and SA coupled with a moderate coating thickness and a high B doping level. 


\section{BDD Electrochemical Performance in Different Concentrations of Electrolyte}

\subsection{Properties of Three $\mathrm{K}_{2} \mathrm{CO}_{3} / \mathrm{KHCO}_{3}$ Electrolytes}

Table S6 Electrolyte properties for the investigation of carbonate and bicarbonate on anodic $\mathrm{H}_{2} \mathrm{O}_{2}$ production.

\begin{tabular}{|c|c|c|c|c|}
\hline Electrolyte Name & $\begin{array}{c}\mathrm{K}_{2} \mathrm{CO}_{3} \text { Concentration } \\
\text { (M) }\end{array}$ & $\begin{array}{l}\mathrm{KHCO}_{3} \text { Concentration } \\
\text { (M) }\end{array}$ & pH & $\begin{array}{l}\text { Conductivity } \\
\left(\mathrm{mS} \mathrm{cm}^{-1}\right)\end{array}$ \\
\hline${ }^{\prime} 0.5 \mathrm{M} \mathrm{K}_{2} \mathrm{CO}_{3} / \mathrm{KHCO}_{3}{ }^{\prime}$ & 0.5 & 0.5 & 9.85 & 116.5 \\
\hline$' 1 \mathrm{M} \mathrm{K}_{2} \mathrm{CO}_{3} / \mathrm{KHCO}_{3}{ }^{\prime}$ & 1 & 1 & 9.8 & 188.0 \\
\hline '2 $\mathrm{M} \mathrm{K}_{2} \mathrm{CO}_{3} / \mathrm{KHCO}_{3}{ }^{\prime}$ & 2 & 2 & 10 & 233.0 \\
\hline
\end{tabular}

6.2 Results from Experiments Using BDD-4 and $\mathrm{BDD}-5$ in 0.5, 1 and $2 \mathrm{M} \mathrm{K}_{2} \mathrm{CO}_{3} / \mathrm{KHCO}_{3}$

Table S7 Values achieved for $\left[\mathrm{H}_{2} \mathrm{O}_{2}\right]$, partial $j, \% F E$ and $v_{\mathrm{H}_{2} \mathrm{O}_{2}}$ using BDD-4 and BDD-5 in $0.5,1$ and $2 \mathrm{M} \mathrm{K}_{2} \mathrm{CO}_{3} / \mathrm{KHCO}_{3}$

\begin{tabular}{|c|c|c|c|c|c|}
\hline \multicolumn{6}{|c|}{$0.5 \mathrm{M} \mathrm{K}_{2} \mathrm{CO}_{3} / \mathrm{KHCO}_{3}$ BDD-4 } \\
\hline E vs. RHE (V) & $\begin{array}{c}j_{\text {Total }} \\
\left(\mathrm{mA} \mathrm{cm}^{-2}\right)\end{array}$ & $\begin{array}{c}j_{\mathrm{H}_{2} \mathrm{O}_{2}} \\
\left(\mathrm{~mA} \mathrm{~cm}^{-2}\right)\end{array}$ & $\mathrm{H}_{2} \mathrm{O}_{2}(\mathrm{mM})$ & FE (\%) & $V_{\mathrm{H}_{2} \mathrm{O}_{2}}\left(\mu \mathrm{mol} \mathrm{cm} \mathrm{cm}^{-2} \mathrm{~min}^{-1}\right)$ \\
\hline 2.80 & 50 & 27 & 11.4 & 54 & 8.3 \\
\hline 2.94 & 100 & 63 & 26.5 & 63 & 19.4 \\
\hline 3.06 & 150 & 94 & 39.8 & 63 & 29.1 \\
\hline 3.12 & 200 & 126 & 53.5 & 63 & 39.1 \\
\hline 3.26 & 250 & 158 & 66.9 & 63 & 48.9 \\
\hline 3.38 & 300 & 182 & 77.0 & 60 & 56.3 \\
\hline \multicolumn{6}{|c|}{$0.5 \mathrm{M} \mathrm{K}_{2} \mathrm{CO}_{3} / \mathrm{KHCO}_{3}$ BDD-5 } \\
\hline E vs. RHE (V) & $\begin{array}{c}j_{\text {Total }} \\
\left(\mathrm{mA} \mathrm{cm}^{-2}\right)\end{array}$ & $\begin{array}{c}j_{\mathrm{H}_{2} \mathrm{O}_{2}} \\
\left(\mathrm{~mA} \mathrm{~cm}^{-2}\right)\end{array}$ & $\mathrm{H}_{2} \mathrm{O}_{2}(\mathrm{mM})$ & FE (\%) & $V_{\mathrm{H}_{2} \mathrm{O}_{2}}\left(\mu \mathrm{mol} \mathrm{cm} \mathrm{cm}^{-2} \mathrm{~min}^{-1}\right)$ \\
\hline 2.89 & 50 & 24 & 12.9 & 48 & 7.5 \\
\hline 2.97 & 100 & 53 & 28.4 & 53 & 16.4 \\
\hline 3.21 & 150 & 86 & 46.1 & 57 & 26.6 \\
\hline 3.23 & 200 & 107 & 57.4 & 53 & 33.1 \\
\hline 3.45 & 250 & 129 & 69.6 & 52 & 40.1 \\
\hline 3.61 & 300 & 145 & 78.1 & 48 & 45.0 \\
\hline \multicolumn{6}{|c|}{$1 \mathrm{M} \mathrm{K}_{2} \mathrm{CO}_{3} / \mathrm{KHCO}_{3}$ BDD-4 } \\
\hline E vs. RHE (V) & $\begin{array}{c}j_{\text {Total }} \\
\left(\mathrm{mA} \mathrm{cm}^{-2}\right)\end{array}$ & $\begin{array}{c}j_{\mathrm{H}_{2} \mathrm{O}_{2}} \\
\left(\mathrm{~mA} \mathrm{~cm}^{-2}\right)\end{array}$ & $\mathrm{H}_{2} \mathrm{O}_{2}(\mathrm{mM})$ & FE (\%) & $V_{\mathrm{H}_{2} \mathrm{O}_{2}}\left(\mu \mathrm{mol} \mathrm{cm} \mathrm{cmin}^{-1}\right)$ \\
\hline 2.66 & 50 & 28 & 12.0 & 57 & 8.8 \\
\hline 2.79 & 100 & 66 & 27.8 & 66 & 20.3 \\
\hline 2.91 & 150 & 98 & 41.7 & 66 & 30.5 \\
\hline 3.00 & 200 & 140 & 59.2 & 70 & 43.3 \\
\hline 3.05 & 250 & 173 & 73.5 & 69 & 53.7 \\
\hline 3.10 & 300 & 208 & 88.2 & 69 & 64.5 \\
\hline \multicolumn{6}{|c|}{$1 \mathrm{M} \mathrm{K}_{2} \mathrm{CO}_{3} / \mathrm{KHCO}_{3}$ BDD-5 } \\
\hline
\end{tabular}




\begin{tabular}{|c|c|c|c|c|c|}
\hline E vs. RHE (V) & $\begin{array}{c}j_{\text {Total }} \\
\left(\mathrm{mA} \mathrm{cm}^{-2}\right)\end{array}$ & $\begin{array}{c}j_{\mathrm{H}_{2} \mathrm{O}_{2}} \\
\left(\mathrm{~mA} \mathrm{~cm}^{-2}\right)\end{array}$ & $\mathrm{H}_{2} \mathrm{O}_{2}(\mathrm{mM})$ & FE (\%) & $V_{\mathrm{H}_{2} \mathrm{O}_{2}}\left(\mu \mathrm{mol} \mathrm{cm}^{-2} \mathrm{~min}^{-1}\right)$ \\
\hline 2.64 & 50 & 26 & 13.9 & 52 & 8.0 \\
\hline 2.73 & 100 & 62 & 33.3 & 62 & 19.2 \\
\hline 2.78 & 150 & 102 & 54.7 & 68 & 31.5 \\
\hline 2.84 & 200 & 120 & 64.8 & 60 & 37.3 \\
\hline 2.92 & 250 & 150 & 80.8 & 60 & 46.6 \\
\hline 2.95 & 300 & 168 & 90.4 & 56 & 52.1 \\
\hline \multicolumn{6}{|c|}{$2 \mathrm{M} \mathrm{K}_{2} \mathrm{CO}_{3} / \mathrm{KHCO}_{3} \mathrm{BDD}-4$} \\
\hline E vs. RHE (V) & $\begin{array}{c}j_{\text {Total }} \\
\left(\mathrm{mA} \mathrm{cc^{-2 }}\right)\end{array}$ & $\begin{array}{c}j_{\mathrm{H}_{2} \mathrm{O}_{2}} \\
\left.(\mathrm{~mA} \mathrm{~cm})^{-2}\right)\end{array}$ & $\mathrm{H}_{2} \mathrm{O}_{2}(\mathrm{mM})$ & FE (\%) & $V_{\mathrm{H}_{2} \mathrm{O}_{2}}\left(\mu \mathrm{mol} \mathrm{cm} \mathrm{cm}^{-2} \mathrm{~min}^{-1}\right)$ \\
\hline 2.61 & 50 & 37 & 15.7 & 74 & 11.4 \\
\hline 2.72 & 100 & 84 & 35.6 & 84 & 26.1 \\
\hline 2.78 & 150 & 129 & 54.6 & 86 & 39.9 \\
\hline 2.85 & 200 & 174 & 73.6 & 87 & 53.8 \\
\hline 2.93 & 250 & 215 & 91.1 & 86 & 66.6 \\
\hline 3.02 & 300 & 247 & 104.6 & 82 & 76.4 \\
\hline \multicolumn{6}{|c|}{$2 \mathrm{M} \mathrm{K}_{2} \mathrm{CO}_{3} / \mathrm{KHCO}_{3}$ BDD-5 } \\
\hline E vs. RHE (V) & $\begin{array}{c}j_{\text {Total }} \\
\left(\mathrm{mA} \mathrm{cm}^{-2}\right)\end{array}$ & $\begin{array}{c}j_{\mathrm{H}_{2} \mathrm{O}_{2}} \\
\left.(\mathrm{~mA} \mathrm{~cm})^{-2}\right)\end{array}$ & $\mathrm{H}_{2} \mathrm{O}_{2}(\mathrm{mM})$ & FE (\%) & $V_{\mathrm{H}_{2} \mathrm{O}_{2}}\left(\mu \mathrm{mol} \mathrm{cm} \mathrm{cm}^{-2} \mathrm{~min}^{-1}\right)$ \\
\hline 2.58 & 50 & 35 & 18.8 & 70 & 10.8 \\
\hline 2.65 & 100 & 76 & 40.7 & 76 & 23.5 \\
\hline 2.75 & 150 & 117 & 63.0 & 78 & 36.3 \\
\hline 2.78 & 200 & 151 & 81.1 & 75 & 46.7 \\
\hline 2.84 & 250 & 183 & 98.5 & 73 & 56.7 \\
\hline 2.88 & 300 & 201 & 108.2 & 67 & 62.3 \\
\hline
\end{tabular}




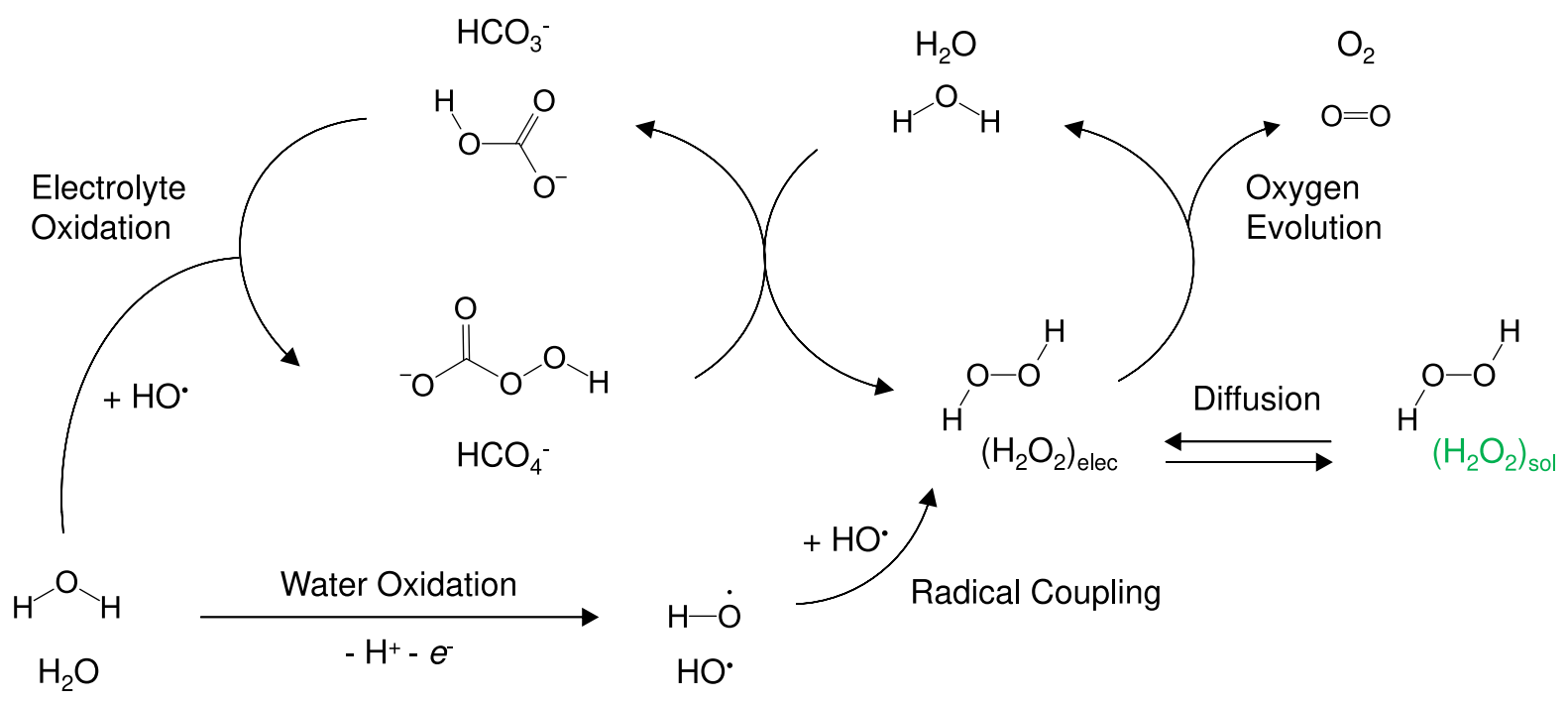

Figure S11 Proposed pathway for the electrochemical production of $\mathrm{H}_{2} \mathrm{O}_{2}$ via water oxidation using BDD films in $\mathrm{K}_{2} \mathrm{CO}_{3} / \mathrm{KHCO}_{3}$ solutions.

Initially, it is postulated that hydroxyl radicals ( $\left.\mathrm{HO}^{\circ}\right)$ are generated at the BDD surface via a oneelectron water oxidation reaction (Equation S6). ${ }^{25-28}$ The generated $\mathrm{HO}^{\circ}$ can participate in numerous subsequent and simultaneously-occurring reactions, primarily oxidation of the supporting electrolyte and radical recombination..$^{29,30}$

$$
\mathrm{H}_{2} \mathrm{O} \rightleftharpoons \mathrm{HO}^{\bullet}+\mathrm{H}^{+}+e^{-} \quad E^{\circ}=2.73 \mathrm{~V} \text { vs. RHE }
$$

Concerning the oxidation of the supporting electrolyte, two main steps are proposed. First, the $\mathrm{HO}^{\bullet}$ will react with carbonate and bicarbonate to form the percarbonate intermediates $\mathrm{HCO}_{4}{ }^{-}$and $\mathrm{C}_{2} \mathrm{O}_{6}{ }^{2-}$ (Equations S7a-d). ${ }^{31-34}$

$$
\begin{aligned}
& 2 \mathrm{HO}^{\circ}+\mathrm{HCO}_{3}{ }^{-} \rightarrow \mathrm{HCO}_{4}{ }^{-}+\mathrm{H}_{2} \mathrm{O} \\
& 2 \mathrm{HO}^{\circ}+2 \mathrm{HCO}_{3}{ }^{-} \rightarrow \mathrm{C}_{2} \mathrm{O}_{6}{ }^{2-}+2 \mathrm{H}_{2} \mathrm{O} \\
& 2 \mathrm{HO}^{\circ}+\mathrm{CO}_{3}{ }^{2-} \rightarrow \mathrm{HCO}_{4}{ }^{-}+\mathrm{OH}^{-} \\
& 2 \mathrm{HO}^{\circ}+2 \mathrm{CO}_{3}{ }^{2-} \rightarrow \mathrm{C}_{2} \mathrm{O}_{6}{ }^{2-}+2 \mathrm{OH}^{-}
\end{aligned}
$$

Then, the produced percarbonate intermediates will be hydrolysed (Equations $\mathbf{S 8 a}$ \& $\mathbf{8 b}$ ) to form $\mathrm{H}_{2} \mathrm{O}_{2}$ at the surface of the electrode, and $\mathrm{HCO}_{3}{ }^{-}$which can once again undergo oxidation by $\mathrm{HO}^{\circ}$ thereby recommencing the electrolyte oxidation reaction cycle. ${ }^{35}$ 


$$
\begin{aligned}
& \mathrm{HCO}_{4}^{-}+\mathrm{H}_{2} \mathrm{O} \rightarrow \mathrm{H}_{2} \mathrm{O}_{2} \text { (elec) }+\mathrm{HCO}_{3}^{-} \\
& \mathrm{C}_{2} \mathrm{O}_{6}{ }^{2-}+2 \mathrm{H}_{2} \mathrm{O} \rightarrow \mathrm{H}_{2} \mathrm{O}_{2} \text { (elec) }+2 \mathrm{HCO}_{3}^{-}
\end{aligned}
$$

Synchronous to the oxidation of the electrolyte is the recombination of the generated hydroxyl radicals to form $\mathrm{H}_{2} \mathrm{O}_{2}$ (Equation $\mathrm{S9a}$ ). ${ }^{36-38} \mathrm{H}_{2} \mathrm{O}_{2}$ produced near the surface of the electrode will diffuse into the bulk solution to avoid degradation (Equation S9b). Hydrogen peroxide that does remain close to the surface of BDD will be oxidised to oxygen (Equation S9c). Thus, a reported faradaic efficiency of less than $100 \%$ for the $2 e^{-}$WOR indicates that any produced $\mathrm{H}_{2} \mathrm{O}_{2}$ may well be further oxidised to $\mathrm{O}_{2}$ during the water oxidation reaction. A certain amount of $\mathrm{H}_{2} \mathrm{O}_{2}$ will also spontaneously dissociate to water and oxygen (Equation S9d) due to the instability of the peroxide bond.

$$
\begin{aligned}
& \mathrm{OH}^{\bullet}+\mathrm{OH}^{\bullet} \rightarrow \mathrm{H}_{2} \mathrm{O}_{2} \\
& \mathrm{H}_{2} \mathrm{O}_{2 \text { (elec) }} \rightleftharpoons \mathrm{H}_{2} \mathrm{O}_{2 \text { (sol) }} \\
& \mathrm{H}_{2} \mathrm{O}_{2} \text { (elec) } \rightleftharpoons \mathrm{O}_{2}+2 \mathrm{H}^{+}+2 e^{-} \\
& 2 \mathrm{H}_{2} \mathrm{O}_{2} \rightarrow 2 \mathrm{H}_{2} \mathrm{O}+\mathrm{O}_{2}
\end{aligned}
$$

Finally, it is worth considering that the graphene impurities within the BDD coating $\left(C_{B D D}\right)$ may react with $\mathrm{HO}^{-}$to evolve $\mathrm{CO}_{2}$ (Equation S10). ${ }^{29,39}$ The oxidation of carbon in the BDD film may account for the determined increase of the $\mathrm{sp}^{3} / \mathrm{sp}^{2}$ carbon ratio following multiple electrolyses using BDD. ${ }^{7}$

$$
\mathrm{CBDD}_{\mathrm{BD}}+\mathrm{OH}^{\cdot} \rightarrow \mathrm{CO}_{2}+2 \mathrm{H}^{+}+2 e^{-}
$$

To acquire a better understanding of the proposed mechanistic pathway, density functional theory (DFT) is implemented to calculate the Gibbs Free Energy of the intermediates formed during the suggested reactions. The change in the Gibbs Free Energy $(\Delta G)$, of the proposed mechanistic pathways is presented in Table S8.

The standard calculations were performed using Gaussian software via density functional theory (DFT), the Becke, three-parameter, Lee-Yang-Parr exchange correlation (B3LYP) hybrid functional and the $6-31+G(d, p)$ basis set for low molecular weight molecules (ex. non-metals). The total energy, $E_{\text {total, }}$ often expressed as self-consistent field (SCF) energy, was obtained through optimisation calculations, in which the geometry was optimised with ab initio methods.

The frequency calculations consider the changes in enthalpy and entropy concerning thermochemical properties. Since the Gibbs Free Energy is defined as $G^{\circ}=H^{\circ}-\left(T \times S^{\circ}\right)$, and enthalpy is defined as $H=$ $E_{\text {total }}+\left(k_{\mathrm{B}} \times T\right)$, the Gibbs Free Energy phase is given by $G^{\circ}=E_{\text {total }}+\left(k_{\mathrm{B}} \times T\right)-\left(T \times S^{\circ}\right)$, where $k_{\mathrm{B}}$ and $S$ are the Boltzmann constant and entropy, respectively. A thermal correction term was obtained from vibrational frequency calculations and is used to convert the SCF Energy into Gibbs Free Energy. 
Table S8 Self-consistent field (SCF) energy and Gibbs Free Energy of the reactants, intermediates and products, and the calculated change in the Gibbs Free Energy of the proposed reaction pathways for the electrochemical generation of $\mathrm{H}_{2} \mathrm{O}_{2}$ via water oxidation in $\mathrm{K}_{2} \mathrm{CO}_{3} / \mathrm{KHCO}_{3}$.

\begin{tabular}{|c|c|c|c|c|}
\hline Name & Molecule & $\begin{array}{l}\text { SCF Energy } \\
\text { (a.u.) }\end{array}$ & $\begin{array}{c}\text { Thermal Correction to } \\
\text { Free Energy (a.u.) }\end{array}$ & $\begin{array}{c}\text { Gibbs Free } \\
\text { Energy (a.u.) }\end{array}$ \\
\hline Hydroxyl radical & $\dot{\mathrm{O}}-\mathrm{H}$ & -75.739014 & -0.008503 & -75.747517 \\
\hline Hydroxide ion & $\mathrm{O}-\mathrm{H}$ & -75.803434 & -0.007712 & -75.811146 \\
\hline Water & & -76.434049 & 0.00364 & -76.430409 \\
\hline Hydrogen peroxide & & -151.557135 & 0.003596 & -151.553539 \\
\hline Carbonate ion & $\mathrm{O}^{-}$ & -263.698676 & -0.012367 & -263.711043 \\
\hline Bicarbonate ion & $\mathrm{O}^{-}$ & -264.476589 & 0.000233 & -264.476356 \\
\hline Peroxymonocarbonate & & -339.605131 & 0.000094 & -339.605037 \\
\hline Peroxydicarbonate & & -527.542392 & -0.001163 & -527.543555 \\
\hline Equation & \multicolumn{2}{|c|}{\begin{tabular}{c|c}
$\mathrm{O}^{-}$ & \\
Chemical Reaction
\end{tabular}} & \multicolumn{2}{|c|}{ Change in Gibbs Free Energy, $\Delta G$ (a.u.) } \\
\hline (S7a) & \multicolumn{2}{|c|}{$2 \mathrm{HO}^{-}+\mathrm{HCO}_{3}^{-} \rightarrow \mathrm{HCO}_{4}^{-}+\mathrm{H}_{2} \mathrm{O}$} & \multicolumn{2}{|c|}{-0.064056} \\
\hline (S7b) & \multicolumn{2}{|c|}{$2 \mathrm{HO}^{\circ}+2 \mathrm{HCO}_{3}^{-} \rightarrow \mathrm{C}_{2} \mathrm{O}_{6}{ }^{2-}+2 \mathrm{H}_{2} \mathrm{O}$} & \multicolumn{2}{|c|}{0.043373} \\
\hline (S7c) & \multicolumn{2}{|c|}{$2 \mathrm{HO}^{-}+\mathrm{CO}_{3}^{2-} \rightarrow \mathrm{HCO}_{4}^{-}+\mathrm{OH}^{-}$} & \multicolumn{2}{|c|}{-0.210106} \\
\hline (S7d) & \multicolumn{2}{|c|}{$2 \mathrm{HO}^{\circ}+2 \mathrm{CO}_{3}{ }^{2-} \rightarrow \mathrm{C}_{2} \mathrm{O}_{6}{ }^{2-}+2 \mathrm{OH}^{-}$} & \multicolumn{2}{|c|}{-0.248727} \\
\hline (S8a) & \multicolumn{2}{|c|}{$\mathrm{HCO}_{4}^{-}+\mathrm{H}_{2} \mathrm{O} \rightarrow \mathrm{H}_{2} \mathrm{O}_{2}+\mathrm{HCO}_{3}^{-}$} & \multicolumn{2}{|c|}{0.005551} \\
\hline$(\mathrm{S} 8 \mathrm{~b})$ & \multicolumn{2}{|c|}{$\mathrm{C}_{2} \mathrm{O}_{6}{ }^{2-}+2 \mathrm{H}_{2} \mathrm{O} \rightarrow \mathrm{H}_{2} \mathrm{O}_{2}+2 \mathrm{HCO}_{3}^{-}$} & \multicolumn{2}{|c|}{-0.101878} \\
\hline
\end{tabular}

The simple DFT calculations carried out show that the formation of $\mathrm{C}_{2} \mathrm{O}_{6}{ }^{2-}$ via oxidation of the bicarbonate ion (Equation S7b) and hydrolysis of peroxymonocarbonate to produce $\mathrm{H}_{2} \mathrm{O}_{2}$ (Equation S8a) are non-spontaneous reactions (positive $\Delta G$ ), thus implying that the presence of a catalyst is required for the reactions to proceed forward. Of the spontaneous reactions (negative $\Delta G$ ), formation of $\mathrm{C}_{2} \mathrm{O}_{6}{ }^{2-}$ via oxidation of the carbonate ion (Equation $\mathrm{S7d}$ ) is more favourable than the formation of $\mathrm{HCO}_{4}^{-}$via oxidation of the carbonate ion (Equation S7c). Both reactions are more favourable than the formation of $\mathrm{HCO}_{4}^{-}$via oxidation of the bicarbonate ion (Equation S7a). The preceding theoretical calculations suggest that the alkaline carbonate ion is preferable for the generation of $\mathrm{H}_{2} \mathrm{O}_{2}$ via water oxidation using $\mathrm{BDD}$, which agrees with the experimentally observed increase in the concentration of $\mathrm{H}_{2} \mathrm{O}_{2}$, from $28.4 \mathrm{mM}$ to $37.7 \mathrm{mM}$, when the concentration of $\mathrm{CO}_{3}{ }^{2-}$ is increased from $1 \mathrm{M}$ to $4 \mathrm{M} \mathrm{K}_{2} \mathrm{CO}_{3}$ (Figure S12a). At higher $\mathrm{K}_{2} \mathrm{CO}_{3}$ concentrations, a greater selectivity toward the $2 e^{-}$WOR is observed with the \%FE reaching an unprecedented value of $91 \%$ in $4 \mathrm{M} \mathrm{K}_{2} \mathrm{CO}_{3}$ using BDD-4 when an electrical current of $100 \mathrm{~mA} \mathrm{~cm}^{-2}$ is applied (Figure S12b), corresponding to an overpotential of just $1054 \mathrm{mV}$ and thus further corroborating the positive influence of $\mathrm{CO}_{3}{ }^{2-}$ and other $\mathrm{CO}_{2} / \mathrm{HCO}_{3}{ }^{-}$intermediate species on $\mathrm{H}_{2} \mathrm{O}_{2}$ electro-generation via water oxidation. 
(a)

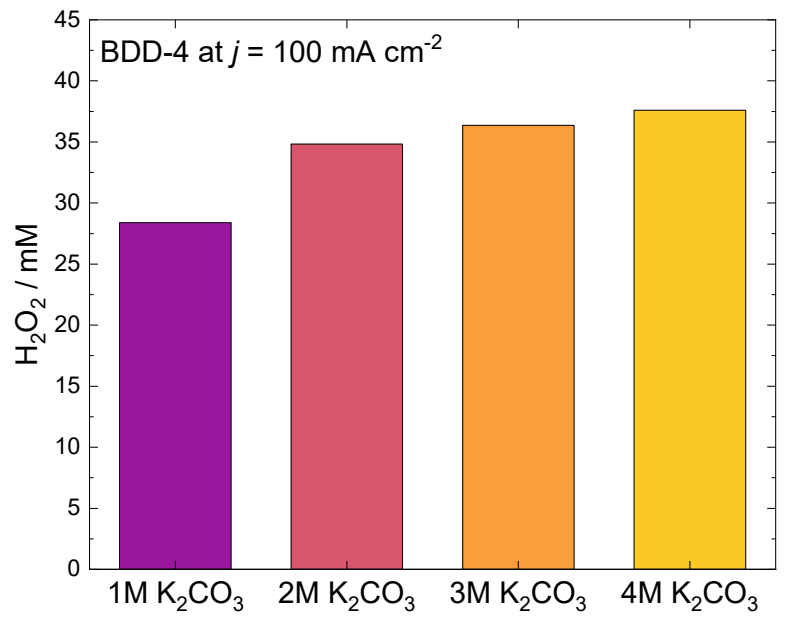

(b)

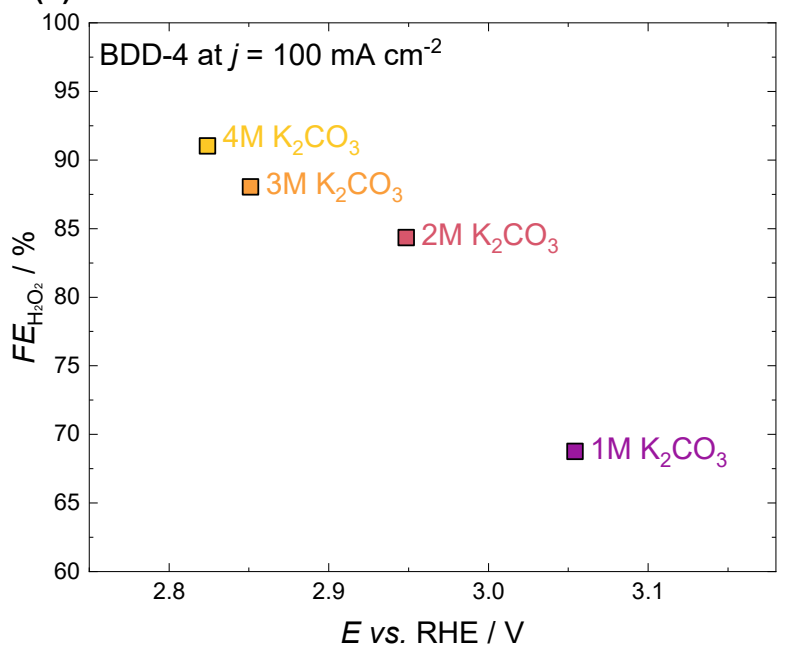

Figure $\mathrm{S} 12$ (a) $\mathrm{H}_{2} \mathrm{O}_{2}$ concentration following electrolysis at a constant current of $100 \mathrm{~mA} \mathrm{~cm}{ }^{-2}$ for $300 \mathrm{~s}$ using BDD-4 (SA: 6.66 $\mathrm{cm}^{2}$ ) in four different $\mathrm{K}_{2} \mathrm{CO}_{3}$ solutions with a concentration range of 1-4 M. (b) \%FE for $\mathrm{H}_{2} \mathrm{O}_{2}$ production at $100 \mathrm{~mA} \mathrm{~cm}{ }^{-2}$ in 1-4 $\mathrm{M} \mathrm{K}_{2} \mathrm{CO}_{3}$ as a function of the recorded electrode potential (RHE). 


\section{Total and Partial Current Densities Attained using BDD}

The partial current density, $j_{\mathrm{H}_{2}} \mathrm{O}_{2}$, is calculated by multiplying the $\% F E$ for $\mathrm{H}_{2} \mathrm{O}_{2}$ electrosynthesis via the $2 e^{-}$WOR by the overall applied current density, $j_{\text {Total }}$, as seen in Equation $\mathbf{S 1 1}$.

$$
j_{\mathrm{H}_{2} \mathrm{O}_{2}}=F E_{\left(2 e^{-} \text {WOR }\right)} \times j_{\text {Total }}
$$

The partial and total current densities using $\mathrm{BDD}$ in $\mathrm{K}_{2} \mathrm{CO}_{3} / \mathrm{KHCO}_{3}$ can be seen in Figure $\mathbf{S} 13$.

(a)

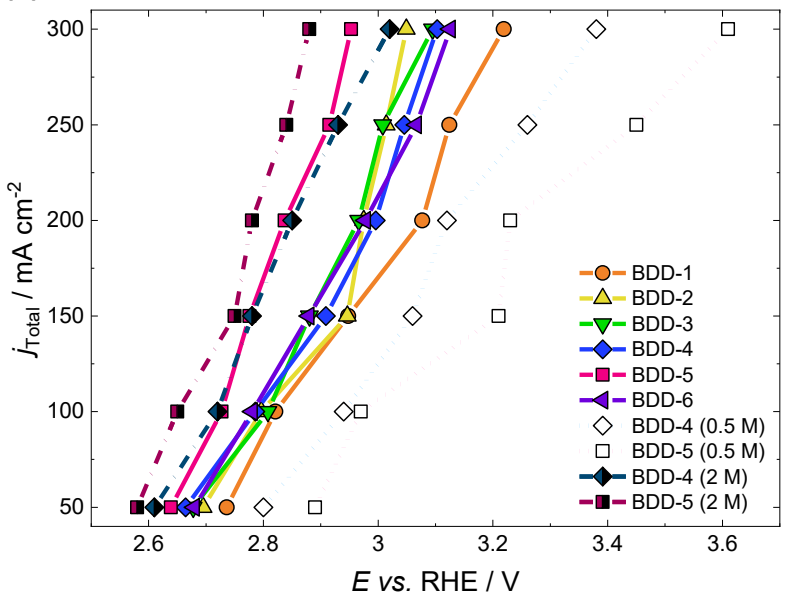

(b)

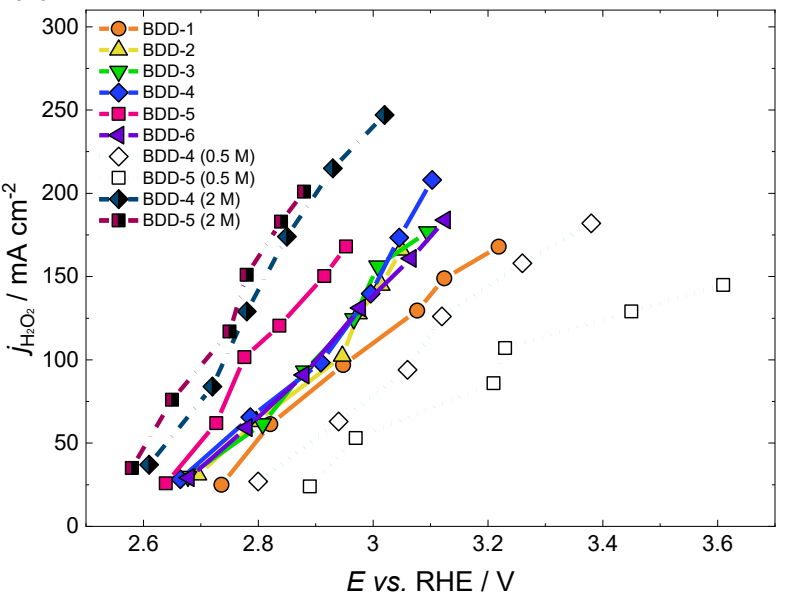

Figure $\mathbf{S 1 3}$ (a) Total current density for BDD films in $1 \mathrm{M} \mathrm{K}_{2} \mathrm{CO}_{3} / \mathrm{KHCO}_{3}$, as well as BDD-4 and BDD-5 in $0.5 \mathrm{M}$ and $2 \mathrm{M}$ $\mathrm{K}_{2} \mathrm{CO}_{3} / \mathrm{KHCO}_{3}$. (b) Partial current density for BDD films in $1 \mathrm{M} \mathrm{K}_{2} \mathrm{CO}_{3} / \mathrm{KHCO}_{3}$, as well as BDD-4 and BDD-5 in $0.5 \mathrm{M}$ and $2 \mathrm{M}$ $\mathrm{K}_{2} \mathrm{CO}_{3} / \mathrm{KHCO}_{3}$.

The BDD catalysts investigated in this study are subjected to the highest total current densities (up to $300 \mathrm{~mA} \mathrm{~cm}{ }^{-2}$ ) reported, to date, for the $2 e^{-}$WOR to produce $\mathrm{H}_{2} \mathrm{O}_{2}$ (Figure S13a). The peak partial current densities for each of the six BDD modulated films (Figure S13b) are approximately twice as large as any other reported catalyst, with all BDD films achieving $j_{\mathrm{H}_{2} \mathrm{O}_{2}}$ values above $140 \mathrm{~mA} \mathrm{~cm}$ (Table S9). The highest value, $247 \mathrm{~mA} \mathrm{~cm}{ }^{-2}$, is recorded in $2 \mathrm{M} \mathrm{K}_{2} \mathrm{CO}_{3} / \mathrm{KHCO}_{3}$ using BDD-4. 


\section{Performance Comparison of BDD to Other Prominent $2 e^{-}$WOR Electrocatalysts}

Table S9 Performance-related parameters of $2 e^{-}$WOR electrocatalysts. NB: 'Combined' refers to the mixed $\mathrm{K}_{2} \mathrm{CO}_{3} / \mathrm{KHCO}_{3}$

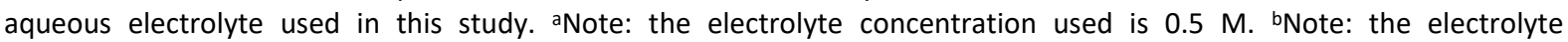
concentration used is $2 \mathrm{M}$.

\begin{tabular}{|c|c|c|c|c|c|c|c|}
\hline Catalyst & Electrolyte & pH & \begin{tabular}{|l|} 
Max $j_{\text {Total }}$ \\
$\left(\mathrm{mA} \mathrm{cm} \mathbf{c m}^{-2}\right)$
\end{tabular} & $\begin{array}{l}\mathrm{Max} j_{\mathrm{H}_{2} \mathrm{O}_{2}} \\
(\mathrm{~mA} \mathrm{~cm}\end{array}$ & $\begin{array}{l}\text { Peak } \\
\text { FE (\%) }\end{array}$ & $\begin{array}{c}\operatorname{Max} v_{\mathrm{H}_{2} \mathrm{O}_{2}} \\
\left(\mu \mathrm{mol} \mathrm{cm} \mathrm{min}^{-1}\right)\end{array}$ & Ref. \\
\hline BDD-1 & $1 \mathrm{M}$ Combined & 9.8 & 300 & 168 & 65 & 52 & This work \\
\hline BDD-2 & $1 \mathrm{M}$ Combined & 9.8 & 300 & 166 & 68 & 51.4 & This work \\
\hline BDD-3 & $1 \mathrm{M}$ Combined & 9.8 & 300 & 177 & 63 & 54.8 & This work \\
\hline BDD-4 & $1 \mathrm{M}$ Combined & 9.8 & 300 & 208 & 70 & 64.5 & This work \\
\hline BDD-5 & $1 \mathrm{M}$ Combined & 9.8 & 300 & 168 & 68 & 52.1 & This work \\
\hline BDD-6 & $1 \mathrm{M}$ Combined & 9.8 & 300 & 184 & 66 & 57 & This work \\
\hline BDD-4 ${ }^{a}$ & $0.5 \mathrm{M}$ Combined & 9.85 & 300 & 182 & 63 & 56.3 & This work \\
\hline BDD-5 $^{a}$ & $0.5 \mathrm{M}$ Combined & 9.85 & 300 & 145 & 57 & 45 & This work \\
\hline BDD-4 $^{b}$ & $2 \mathrm{M}$ Combined & 10 & 300 & 247 & 87 & 76.4 & This work \\
\hline BDD-5 $^{b}$ & 2M Combined & 10 & 300 & 201 & 78 & 67.3 & This work \\
\hline $\mathrm{BiVO}_{4}$ & $1 \mathrm{M} \mathrm{NaHCO}_{3}$ & 8.3 & $\sim 2.8$ & 1.96 & 70 & 5.77 & (40) \\
\hline $\mathrm{WO}_{3}$ & $1 \mathrm{M} \mathrm{NaHCO}_{3}$ & 8.3 & $\sim 1.5$ & 0.72 & 48 & 0.57 & (40) \\
\hline $\mathrm{TiO}_{2}$ & $1 \mathrm{M} \mathrm{NaHCO}_{3}$ & 8.3 & $\sim 0.3$ & 0.057 & 19 & 1.01 & (40) \\
\hline $\mathrm{SnO}_{2}$ & $1 \mathrm{M} \mathrm{NaHCO}_{3}$ & 8.3 & $\sim 0.6$ & 0.3 & 50 & 1.53 & $(40)$ \\
\hline $\mathrm{CaSnO}_{3}$ & $2 \mathrm{M} \mathrm{KHCO}_{3}$ & 8.3 & $\sim 37$ & 25.84 & 76 & 4.6 & (41) \\
\hline $\mathrm{ZnO}$ & $2 \mathrm{M} \mathrm{KHCO}_{3}$ & 8.3 & $\sim 17.5$ & 14.2 & 81 & 4.15 & $(42)$ \\
\hline $6 \% G d: \mathrm{BiVO}_{4}$ & $2 \mathrm{M} \mathrm{KHCO}_{3}$ & 8.3 & 50 & 32.5 & 78 & 10.6 & (43) \\
\hline $\mathrm{Bi}_{2} \mathrm{WO}_{6}: 5 \% \mathrm{Mo}$ & $2 \mathrm{M} \mathrm{KHCO}_{3}$ & $\mathrm{n} / \mathrm{a}$ & 10 & 7.9 & 79 & 5 & (44) \\
\hline PTFE/CFP-60\% & $1 \mathrm{M} \mathrm{Na}_{2} \mathrm{CO}_{3}$ & 11.96 & 200 & 68 & 66 & 23.4 & (45) \\
\hline $\mathrm{BDD} / \mathrm{Ti}$ & $2 \mathrm{M} \mathrm{KHCO}_{3}$ & 8 & 295.2 & 66.5 & 28 & 19.7 & (46) \\
\hline $\mathrm{Sb}_{2} \mathrm{O}_{3}$ & $2 \mathrm{M} \mathrm{KHCO}_{3}$ & 8.1 & $\sim 5.5$ & 0.77 & 40.1 & 0.26 & (47) \\
\hline $\mathrm{CaSnO}_{3} @ \mathrm{CF}-2$ & $2 \mathrm{M} \mathrm{KHCO}_{3}$ & $\mathrm{n} / \mathrm{a}$ & 119 & 89.25 & $\sim 90$ & 39.8 & (48) \\
\hline
\end{tabular}




\section{BDD Cost Estimation}

The price of $1 \mathrm{~cm}^{2}$ of BDD supported on niobium with a coating thickness of $12 \mu \mathrm{m}$ is estimated to be approximately $€ 1.9$ (based on approximations from several BDD manufacturers). The BDD/Nb electrodes used in this work all have geometric surface areas below $10 \mathrm{~cm}^{2}$ corresponding to a rough value of $€ 19$ per electrode. In highly volatile and acidic environments $\left(1.3 \mathrm{M} \mathrm{H}_{2} \mathrm{SO}_{4}, 70^{\circ} \mathrm{C}\right)$ and large applied current densities $\left(\geq 200 \mathrm{~mA} \mathrm{~cm}^{-2}\right)$, corrosion rates of around $2 \mu \mathrm{m}$ year ${ }^{-1}$ are observed. Thus, the average lifetime of a $10 \mathrm{~cm}^{2} \mathrm{BDD} / \mathrm{Nb}$ electrode in harsh acidic conditions is 6 years with an annual investment of $€ 3.2 \mathrm{~cm}^{-2}$.

The conditions used in this study are not nearly as volatile (potassium carbonate electrolyte, maximum $\mathrm{pH}$ of 10) as the conditions described when utilising concentrated $\mathrm{H}_{2} \mathrm{SO}_{4}$ as a supporting electrolyte, and it is expected that a much longer lifetime, within the order of $10^{2}$ hours, can be achieved. ${ }^{4,49}$ 


\section{References}

(1) Luong, J. H. T.; Male, K. B.; Glennon, J. D. Boron-Doped Diamond Electrode: Synthesis, Characterization, Functionalization and Analytical Applications. Analyst. Royal Society of Chemistry September 21, 2009, pp 1965-1979. https://doi.org/10.1039/b910206j.

(2) Shatynski, S. R. The Thermochemistry of Transition Metal Carbides. Oxid. Met. 1979, 13 (2), 105-118. https://doi.org/10.1007/BF00611975.

(3) Messner, M.; Walczyk, D. J.; Palazzo, B. G.; Norris, Z. A.; Taylor, G.; Carroll, J.; Pham, T. X.; Hettinger, J. D.; Yu, L. Electrochemical Oxidation of Metal Carbides in Aqueous Solutions. J. Electrochem. Soc. 2018, 165 (4), H3107-H3114. https://doi.org/10.1149/2.0171804jes.

(4) Lu, X.-R.; Ding, M.-H.; Zhang, C.; Tang, W.-Z. Comparative Study on Stability of Boron Doped Diamond Coated Titanium and Niobium Electrodes. Diam. Relat. Mater. 2019, 93, 26-33. https://doi.org/10.1016/j.diamond.2019.01.010.

(5) Mortet, V.; Haenen, K.; Nesladek, M.; Vanecek, M.; Bergonzo, P.; D'Olieslaeger, M. Orientation Study with EBSD of Highly Oriented Diamond Films Grown by PECVD; 2005. https://doi.org/10.13140/RG.2.2.34622.54082.

(6) Clausing, R. E. Diamond Morphology. In Handbook of Industrial Diamonds and Diamond Films; CRC Press, 2018; pp 19-47. https://doi.org/10.1201/9780203752807-2.

(7) Chaplin, B. P.; Hubler, D. K.; Farrell, J. Understanding Anodic Wear at Boron Doped Diamond Film Electrodes. Electrochim. Acta 2013, 89, 122-131. https://doi.org/10.1016/j.electacta.2012.10.166.

(8) Abrams, H. Grain Size Measurement by the Intercept Method. Metallography 1971, 4 (1), 5978. https://doi.org/10.1016/0026-0800(71)90005-X.

(9) Lu, X. ru; Ding, M. hui; Zhang, L.; Yang, Z. liang; Lu, Y.; Tang, W. zhong. Optimizing the Microstructure and Corrosion Resistance of BDD Coating to Improve the Service Life of Ti/BDD Coated Electrode. Materials (Basel). 2019, $12 \quad$ (19), 3188. https://doi.org/10.3390/ma12193188.

(10) Bennet, K.; Lee, K.; Kruchowski, J.; Chang, S.-Y.; Marsh, M.; Van Orsow, A.; Paez, A.; Manciu, F. Development of Conductive Boron-Doped Diamond Electrode: A Microscopic, Spectroscopic, and Voltammetric Study. Materials (Basel). 2013, 6 (12), 5726-5741. https://doi.org/10.3390/ma6125726.

(11) Cifre, J.; Puigdollers, J.; Polo, M. C.; Esteve, J. Trimethylboron Doping of CVD Diamond Thin Films. Diam. Relat. Mater. 1994, 3 (4-6), 628-631. https://doi.org/10.1016/09259635(94)90238-0.

(12) Ferreira, N. G.; Abramof, E.; Corat, E. J.; Trava-Airoldi, V. J. Residual Stresses and Crystalline Quality of Heavily Boron-Doped Diamond Films Analysed by Micro-Raman Spectroscopy and XRay Diffraction. Carbon N. Y. 2003, 41 (6), 1301-1308. https://doi.org/10.1016/S00086223(03)00071-X.

(13) Li, H.; Zhang, T.; Li, L.; Lü, X.; Li, B.; Jin, Z.; Zou, G. Investigation on Crystalline Structure, Boron Distribution, and Residual Stresses in Freestanding Boron-Doped CVD Diamond Films. J. Cryst. Growth 2010, 312 (12-13), 1986-1991. https://doi.org/10.1016/j.jcrysgro.2010.03.020.

(14) Miyata, K.; Kumagai, K.; Nishimura, K.; Kobashi, K. Morphology of Heavily B-Doped Diamond Films. J. Mater. Res. 1993, 8 (11), 2845-2857. https://doi.org/10.1557/JMR.1993.2845. 
(15) Kasahara, S.; Natsui, K.; Watanabe, T.; Yokota, Y.; Kim, Y.; lizuka, S.; Tateyama, Y.; Einaga, Y. Surface Hydrogenation of Boron-Doped Diamond Electrodes by Cathodic Reduction. Anal. Chem. 2017, 89 (21), 11341-11347. https://doi.org/10.1021/acs.analchem.7b02129.

(16) Freitas, J. M.; Oliveira, T. da C.; Munoz, R. A. A.; Richter, E. M. Boron Doped Diamond Electrodes $\begin{array}{llllll}\text { in Flow-Based Systems. Front. Chem. 2019, } 7 \text { (APR), } 190 . & \end{array}$ https://doi.org/10.3389/fchem.2019.00190.

(17) Zielinski, A.; Cieslik, M.; Sobaszek, M.; Bogdanowicz, R.; Darowicki, K.; Ryl, J. Multifrequency Nanoscale Impedance Microscopy (m-NIM): A Novel Approach towards Detection of Selective and Subtle Modifications on the Surface of Polycrystalline Boron-Doped Diamond Electrodes. Ultramicroscopy 2019, 199, 34-45. https://doi.org/10.1016/j.ultramic.2019.01.004.

(18) Yagi, I.; Notsu, H.; Kondo, T.; Tryk, D. A.; Fujishima, A. Electrochemical Selectivity for Redox Systems at Oxygen-Terminated Diamond Electrodes. J. Electroanal. Chem. 1999, 473 (1), 173178. https://doi.org/10.1016/S0022-0728(99)00027-3.

(19) Macpherson, J. V. A Practical Guide to Using Boron Doped Diamond in Electrochemical Research. Phys. Chem. Chem. Phys. 2015, 17 (5), 2935-2949. https://doi.org/10.1039/C4CP04022H.

(20) Muzyka, K.; Sun, J.; Fereja, T. H.; Lan, Y.; Zhang, W.; Xu, G. Boron-Doped Diamond: Current Progress and Challenges in View of Electroanalytical Applications. Anal. Methods 2019, 11 (4), 397-414. https://doi.org/10.1039/c8ay02197j.

(21) Fuku, K.; Miyase, Y.; Miseki, Y.; Gunji, T.; Sayama, K. Enhanced Oxidative Hydrogen Peroxide Production on Conducting Glass Anodes Modified with Metal Oxides. ChemistrySelect 2016, 1 (18), 5721-5726. https://doi.org/10.1002/slct.201601469.

(22) U.S. Geological Survey. Mineral Commodity Summaries; 2019. https://doi.org/10.3133/70202434.

(23) Yang, S.; Verdaguer-Casadevall, A.; Arnarson, L.; Silvioli, L.; Čolić, V.; Frydendal, R.; Rossmeisl, J.; Chorkendorff, I.; Stephens, I. E. L. Toward the Decentralized Electrochemical Production of $\mathrm{H}_{2} \mathrm{O}_{2}$ : A Focus on the Catalysis. ACS Catal. 2018, 8 (5), 4064-4081. https://doi.org/10.1021/acscatal.8b00217.

(24) Kuttassery, F.; Sebastian, A.; Mathew, S.; Tachibana, H.; Inoue, H. Promotive Effect of Bicarbonate Ion on Two-Electron Water Oxidation to Form $\mathrm{H}_{2} \mathrm{O}_{2}$ Catalyzed by Aluminum Porphyrins. ChemSusChem 2019, 12 (9), 1939-1948. https://doi.org/10.1002/cssc.201900560.

(25) Iniesta, J.; Michaud, P. A.; Panizza, M.; Cerisola, G.; Aldaz, A.; Comninellis, C. H. Electrochemical Oxidation of Phenol at Boron-Doped Diamond Electrode. Electrochim. Acta 2001, 46 (23), 3573-3578. https://doi.org/10.1016/S0013-4686(01)00630-2.

(26) Marselli, B.; Garcia-Gomez, J.; Michaud, P.-A.; Rodrigo, M. A.; Comninellis, C. Electrogeneration of Hydroxyl Radicals on Boron-Doped Diamond Electrodes. J. Electrochem. Soc. 2003, 150 (3), D79. https://doi.org/10.1149/1.1553790.

(27) Enache, T. A.; Chiorcea-Paquim, A. M.; Fatibello-Filho, O.; Oliveira-Brett, A. M. Hydroxyl Radicals Electrochemically Generated in Situ on a Boron-Doped Diamond Electrode. $\begin{array}{lllll}\text { Electrochem. Commun. } & \text { 2009, } & \text { (7), 1342-1345. }\end{array}$ https://doi.org/10.1016/j.elecom.2009.04.017.

(28) Espinoza, L. C.; Henríquez, A.; Contreras, D.; Salazar, R. Evidence for the Production of Hydroxyl Radicals at Boron-Doped Diamond Electrodes with Different $\mathrm{sp}^{3} / \mathrm{sp}^{2}$ Ratios and Its Relationship with the Anodic Oxidation of Aniline. Electrochem. commun. 2018, 90, 30-33. 
https://doi.org/10.1016/j.elecom.2018.03.007.

(29) Michaud, P. A.; Panizza, M.; Ouattara, L.; Diaco, T.; Foti, G.; Comninellis, C. Electrochemical Oxidation of Water on Synthetic Boron-Doped Diamond Thin Film Anodes. J. Appl. Electrochem. 2003, 33 (2), 151-154. https://doi.org/10.1023/A:1024084924058.

(30) Irkham; Rais, R. R.; Ivandini, T. A.; Fiorani, A.; Einaga, Y. Electrogenerated Chemiluminescence of Luminol Mediated by Carbonate Electrochemical Oxidation at a Boron-Doped Diamond. Anal. Chem. 2021, 93 (4), 2336-2341. https://doi.org/10.1021/acs.analchem.0c04212.

(31) Saha, M. S.; Furuta, T.; Nishiki, Y. Electrochemical Synthesis of Sodium Peroxycarbonate at Boron-Doped Diamond Electrodes. Electrochem. Solid-State Lett. 2003, 6 (7), D5. https://doi.org/10.1149/1.1576050.

(32) Saha, M. S.; Furuta, T.; Nishiki, Y. Conversion of Carbon Dioxide to Peroxycarbonate at BoronDoped Diamond Electrode. Electrochem. Commun. 2004, 6 (2), 201-204. https://doi.org/10.1016/j.elecom.2003.11.014.

(33) Ruiz, E. J.; Ortega-Borges, R.; Jurado, J. L.; Chapman, T. W.; Meas, Y. Simultaneous Anodic and Cathodic Production of Sodium Percarbonate in Aqueous Solution. Electrochem. Solid-State Lett. 2008, 12 (1), E1. https://doi.org/10.1149/1.3005555.

(34) Irkham; Fiorani, A.; Valenti, G.; Kamoshida, N.; Paolucci, F.; Einaga, Y. Electrogenerated Chemiluminescence by in Situ Production of Coreactant Hydrogen Peroxide in Carbonate Aqueous Solution at a Boron-Doped Diamond Electrode. J. Am. Chem. Soc. 2020, 142 (3), 15181525. https://doi.org/10.1021/jacs.9b11842.

(35) Fuku, K.; Sayama, K. Efficient Oxidative Hydrogen Peroxide Production and Accumulation in Photoelectrochemical Water Splitting Using a Tungsten Trioxide/Bismuth Vanadate Photoanode. Chem. Commun. 2016, 52 (31), 5406-5409. https://doi.org/10.1039/c6cc01605g.

(36) Vatistas, N. Electrocatalytic Properties of BDD Anodes: Its Loosely Adsorbed Hydroxyl Radicals. Int. J. Electrochem. 2012, 2012, 1-7. https://doi.org/10.1155/2012/507516.

(37) Velazquez-Peña, S.; Sáez, C.; Cañizares, P.; Linares-Hernández, I.; Martínez-Miranda, V.; Barrera-Díaz, C.; Rodrigo, M. A. Production of Oxidants via Electrolysis of Carbonate Solutions with Conductive-Diamond Anodes. Chem. Eng. J. 2013, 230, 272-278. https://doi.org/10.1016/j.cej.2013.06.078.

(38) Ruiz-Ruiz, E. J.; Meas, Y.; Ortega-Borges, R.; Jurado Baizabal, J. L. Electrochemical Production of Peroxocarbonate at Room Temperature Using Conductive Diamond Anodes. Surf. Eng. Appl. Electrochem. 2014, 50 (6), 478-484. https://doi.org/10.3103/S106837551406009X.

(39) Duo, I.; Fujishima, A.; Comninellis, C. Electron Transfer Kinetics on Composite Diamond $\left(\mathrm{sp}^{3}\right)$ Graphite ( $\left(\mathrm{sp}^{2}\right)$ Electrodes. Electrochem. Commun. 2003, 5 (8), 695-700. https://doi.org/10.1016/S1388-2481(03)00169-3.

(40) Shi, X.; Siahrostami, S.; Li, G.-L.; Zhang, Y.; Chakthranont, P.; Studt, F.; Jaramillo, T. F.; Zheng, X.; Nørskov, J. K. Understanding Activity Trends in Electrochemical Water Oxidation to Form Hydrogen Peroxide. Nat. Commun. 2017, 8 (1), 701. https://doi.org/10.1038/s41467-01700585-6.

(41) Park, S. Y.; Abroshan, H.; Shi, X.; Jung, H. S.; Siahrostami, S.; Zheng, X. CaSnO ${ }_{3}$ : An Electrocatalyst for Two-Electron Water Oxidation Reaction to Form $\mathrm{H}_{2} \mathrm{O}_{2}$. ACS Energy Lett. 2019, 4 (1), 352357. https://doi.org/10.1021/acsenergylett.8b02303.

(42) Kelly, S. R.; Shi, X.; Back, S.; Vallez, L.; Park, S. Y.; Siahrostami, S.; Zheng, X.; Nørskov, J. K. ZnO 
As an Active and Selective Catalyst for Electrochemical Water Oxidation to Hydrogen Peroxide. ACS Catal. 2019, 9 (5), 4593-4599. https://doi.org/10.1021/acscatal.8b04873.

(43) Baek, J. H.; Gill, T. M.; Abroshan, H.; Park, S.; Shi, X.; Nørskov, J.; Jung, H. S.; Siahrostami, S.; Zheng, X. Selective and Efficient Gd-Doped $\mathrm{BiVO}_{4}$ Photoanode for Two-Electron Water Oxidation to $\mathrm{H}_{2} \mathrm{O}_{2}$. ACS Energy Lett. 2019, 4 (3), 720-728. https://doi.org/10.1021/acsenergylett.9b00277.

(44) Li, L.; Hu, Z.; Yu, J. C. On-Demand Synthesis of $\mathrm{H}_{2} \mathrm{O}_{2}$ by Water Oxidation for Sustainable Resource Production and Organic Pollutant Degradation. Angew. Chemie - Int. Ed. 2020, 59 (46), 20538-20544. https://doi.org/10.1002/anie.202008031.

(45) Xia, C.; Back, S.; Ringe, S.; Jiang, K.; Chen, F.; Sun, X.; Siahrostami, S.; Chan, K.; Wang, H. Confined Local Oxygen Gas Promotes Electrochemical Water Oxidation to Hydrogen Peroxide. Nat. Catal. 2020, 3 (2), 125-134. https://doi.org/10.1038/s41929-019-0402-8.

(46) Mavrikis, S.; Göltz, M.; Rosiwal, S.; Wang, L.; Ponce de León, C. Boron-Doped Diamond Electrocatalyst for Enhanced Anodic $\mathrm{H}_{2} \mathrm{O}_{2}$ Production. ACS Appl. Energy Mater. 2020, 3 (4), 3169-3173. https://doi.org/10.1021/acsaem.0c00093.

(47) Wang, Y.; Lian, X.; Zhou, Y.; Guo, W.; He, H. Synthesis and Characterization of $\mathrm{Sb}_{2} \mathrm{O}_{3}$ : A Stable Electrocatalyst for Efficient $\mathrm{H}_{2} \mathrm{O}_{2}$ Production and Accumulation and Effective Degradation of Dyes. New J. Chem. 2021, 42, 3963-4776. https://doi.org/10.1039/D1NJ00637A.

(48) Zhang, C.; Lu, R.; Liu, C.; Yuan, L.; Wang, J.; Zhao, Y.; Yu, C. High Yield Electrosynthesis of Hydrogen Peroxide from Water Using Electrospun $\mathrm{CaSnO}_{3} @$ Carbon Fiber Membrane Catalysts with Abundant Oxygen Vacancy. Adv. Funct. Mater. 2021, 2100099. https://doi.org/10.1002/adfm.202100099.

(49) Kraft, A. Doped Diamond: A Compact Review on a New, Versatile Electrode Material. Int. J. Electrochem. Sci. 2007, 2 (5), 355-385. 